Florida International University FIU Digital Commons

$8-8-2000$

\title{
A phenomenological perspective of the lived experiences of Jewish holocaust survivors seeking health care in the United States today
}

Marsha Berger

Florida International University

DOI: $10.25148 /$ etd.FI14051110

Follow this and additional works at: https://digitalcommons.fiu.edu/etd

Part of the Nursing Commons

\section{Recommended Citation}

Berger, Marsha, "A phenomenological perspective of the lived experiences of Jewish holocaust survivors seeking health care in the United States today" (2000). FIU Electronic Theses and Dissertations. 1608.

https://digitalcommons.fiu.edu/etd/1608 


\section{FLORIDA INTERNATIONAL UNIVERSITY}

Miami, Florida

\section{A PHENOMENOLOGICAL PERSPECTIVE OF \\ THE LIVED EXPERIENCES OF JEWISH HOLOCAUST SURVIVORS \\ SEEKING HEALTH CARE IN THE UNITED STATES TODAY}

A thesis submitted in partial fulfillment of the

requirements for the degree of

MASTER OF SCIENCE

in

NURSING

by

Marsha Berger

2000 
To: Dean Ronald Berkman

College of Health and Urban Affairs

This thesis, written by Marsha Berger, and entitled A PHENOMENOLOGICAL PERSPECTIVE OF THE LIVED EXPERIENCES OF JEWISH HOLOCAUST SURVIVORS SEEKING HEALTH CARE IN THE UNTTED STATES TODAY, having been approved in respect to style and intellectual content, is referred to you for judgement.

We have read this thesis and recommend that it be approved.

Sandra Lobar

Robert Nesselroth

Kathleen Blais, Major Professor

Date of Defense: August 8, 2000

The thesis of Marsha Berger is approved.

Dean Ronald Berkman

College of Health and Urban Affairs

Dean Richard L. Campbell Division of Graduate Studies

Florida International University, 2000 
(C) COPYRIGHT 2000 by Marsha Berger

All rights reserved. 


\section{DEDICATION}

I dedicate this Master's thesis to the survivors of the Holocaust who, in sharing their stories, serve to commemorate the millions who did not survive. 


\section{AKNOWLEDGMENTS}

I would like to thank the members of my committee, Dr Sandra Lobar, Dr Kathleen Blais, and Robert Nesselroth for your interest, your guidance, and your time. Thank you also, to Steven Levy, for your technical support.

I would like to give special thanks to Dr Kathleen Blais, my major professor, for your open-mindedness and willingness to get involved with a qualitative study. Thanks also for the numerous hours spent giving attention to details.

I would like to express my appreciation to Rita Hoffrichter, director of the Holocaust Documentation Center at Florida International University, for your cooperation in helping me find the participants of this study. I would also like to express my deepest appreciation to the Holocaust survivors who participated in this study. You were my inspiration.

My heartfelt gratitude goes to my husband Richard. Your love, support, encouragement, and bicycle handling skill gave me the balance I needed. 


\section{A PHENOMENOLOGICAL PERSPECTIVE OF THE LIVED EXPERIENCES OF JEWISH HOLOCAUST SURVIVORS SEEKING HEALTH CARE IN THE UNITED STATES TODAY}

by

Marsha Berger

Florida International University, 2000

Miami, Florida

Professor Kathleen Blais, Major Professor

Seven Jewish Holocaust survivors were interviewed using a phenomenological method to determine the essence of the Jewish Holocaust survivor's experience with health care in the United States today. The transcriptions were analyzed using Colaizzi's approach to phenomenological research. This approach includes extraction of significant statements, from the transcriptions, that described the participant's health care behaviors and needs. Formulated meanings of the significant statements were then organized into six themes: Hiding and Avoidance, Self care, Fear/Trust Dichotomy, Security, Luck, and Need for Understanding. These six themes were forms of protection for the participants, which ultimately led to continued survival, the essence of their experience. Knowledge of their experience may direct the nurse in implementing creative and appropriate nursing interventions to provide comfort and assist the survivor with their needs in today's health care arena. 
$\begin{array}{ll}\text { CHAPTER } & \text { PAGE }\end{array}$

I. INTRODUCTION $\ldots \ldots \ldots \ldots \ldots \ldots \ldots \ldots \ldots \ldots \ldots \ldots \ldots$

II. REVIEW OF THE LITERATURE . . . . . . . . . . . . . 8

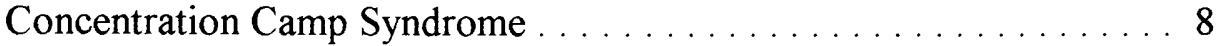

Post Traumatic Stress Disorder in Holocaust Survivors . . . . . . . . 9

Paranoid Psychosis in a Holocaust Survivor . . . . . . . . . . . . . . 13

Major Depression in a Holocaust Survivor . . . . . . . . . . . . . . . 13

Gastrointestinal Disorders . . . . . . . . . . . . . . . . . . . . . . 14

Sleep Disturbances . . . . . . . . . . . . . . . . . . . . . . . . . 14

The Holocaust Survivor with Cancer . . . . . . . . . . . . . . . 16

Child Survivors . . . . . . . . . . . . . . . . . . . . . . . . . . . 18

Therapists'Attitudes towards Holocaust Survivors . . . . . . . . . 20

Holocaust Survivors Entering Nursing Homes. . . . . . . . . . . . . 21

Taping Holocaust Survivors' Stories . . . . . . . . . . . . . . . 22

Transgenerational Effects of the Holocaust . . . . . . . . . . . . 22

Coping and Adaptation . . . . . . . . . . . . . . . . . . 25

Summary . . . . . . . . . . . . . . . . . . . . . . . . 29

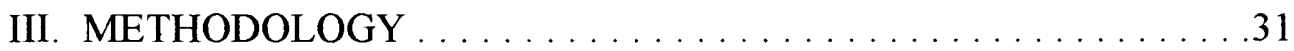

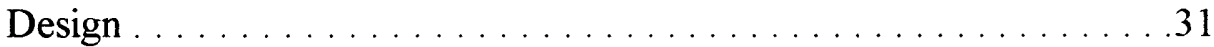

Bracketing of Researcher's Assumptions and Biases . . . . . . . 32

Sample . . . . . . . . . . . . . . . . . . . . . . . . . . . . . 32

Protection of Human Subjects . . . . . . . . . . . . . . . . . . .33

Procedure for Data Analysis . . . . . . . . . . . . . . . . . . . . 34

Method of Data Analysis . . . . . . . . . . . . . . . . . . 36

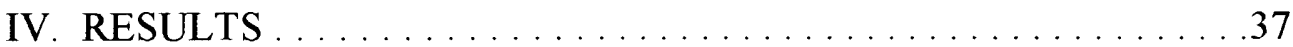

Demographic Data . . . . . . . . . . . . . . . . . . . . . .37

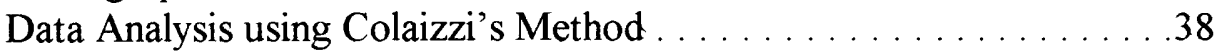

Essence of the Jewish Holocaust Survivors' Experience . . . . . . . 55

Summary. . . . . . . . . . . . . . . . . . . . . . 56

V. CONCLUSIONS . . . . . . . . . . . . . . . . . . 60

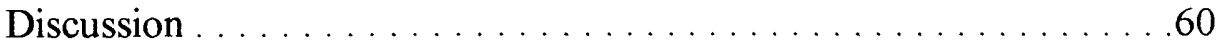

Limitations of the Study . . . . . . . . . . . . . . . . . . . . . . 65

Recommendations for Further Research . . . . . . . . . . . . . 65

Implications for Nursing . . . . . . . . . . . . . . . . . . 66

Summary . . . . . . . . . . . . . . 68

LIST OF REFERENCES . . . . . . . . . . . . . . . . . . . . . . . . . .69

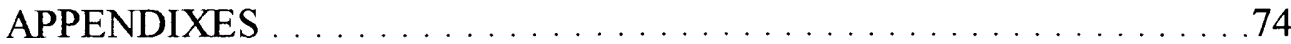




\section{Chapter I}

\section{Introduction}

"Homo homini lupus... man is wolf to man. The bloody chronicles of recorded history have, time and again, demonstrated the truth of this bitter adage but never more clearly than in the treatment of the Jews of Europe in the unrelenting grasp of the German Nazis of the Hitlerian Reich" (Chodoff, 1981, p.2).

History of the Holocaust and the Aftermath for the Survivors

Heinrich Himmler first established the Nazi concentration camps in 1933 for the purpose of internment of the "enemies of the Reich" (Chodoff, 1981). The propaganda that abounded for the 12 years that Hitler and the Nazis ruled was that there were dangerous people who needed to be eliminated in order for German society to flourish. These so-called "dangerous people" were gypsies, Poles, Russians, homosexuals, but centrally and most consistently Jews (Williams, 1993).

In 1942, at a meeting near Berlin, the decision was reached regarding the "Final Solution." In addition to the concerted extermination measures, the environment in the camps was designed to impress upon the Jews their utter worthlessness (Chodoff, 1981). They were degraded, humiliated, and tortured in every conceivable way.

In 1945, World War II ended and the prisoners in the camps were liberated. There were approximately 200,000 to 300,000 European Jews remaining from a population of 6.5 million. The news of the conditions in the death camps spread throughout the allied nations. A British officer recalled the state of the survivors: "Men and women clad in rags, barely able to move from starvation and typhus lay in their wooden bunks in every state of filth and degradation. The dead and dying could not be distinguished"' (Williams, 
1993, p.3). Another account revealed that the inmates had lost all self-respect and were degraded morally to the level of beasts. "Their clothes were in rags, teaming with lice, and both inside and outside of the huts was an almost continuous carpet of dead bodies, human excreta, and filth" (Williams, 1993, p.8).

In addition to the concentration camp prisoners, who managed to survive despite seemingly insurmountable pain, suffering, and hunger, there were some other Jews who survived as well. The partisans were small bands of people who lived in the forests and fought for their existence. There were families who lived in hiding in cupboards, under floorboards, in underground passages and even in coffins. Some infants and young children were sent to England or taken in by non-Jewish families. Regardless of the way in which they survived, the survivors all had something in common. Most of them had lost their entire family and were robbed of their homes and all worldly possessions.

The survivors found their way to displaced persons (DP) camps, where they lived until new homes could be found for them. While still in the DP camps many of the survivors married and gave birth as soon as they were physically able. Creating a new family and having children seemed to be an attempt to compensate for their losses. The children were often viewed as a victory over the Nazis (Williams, 1993).

The majority of the survivors were relocated to the United States, Canada, and Israel (then Palestine). They were penniless immigrants who had to adjust to strange surroundings, learn new languages, and build new lives. "Thanks to the incredible capacity of human beings to adapt and the regenerative powers of the ego, many survivors discovered coping mechanisms in their new surroundings" (Eitinger, 1992 p.8), however the Nazi inflicted trauma created deep wounds. 
For a number of years discussions of the Holocaust were suppressed. The survivors were urged to put it behind them and get on with their lives. There were many suicides after the war. Those whose survival was based on their will to "tell the world" felt betrayed by a world that simply did not want to hear about it (Eitinger, 1992).

It was not until 1961 that William Neiderland, a psychoanalyst, coined the term "Survivor Syndrome." The features of this syndrome were as follows:

1.Depression, withdrawal, insecurity, and apathy alternating with angry outbursts.

2. Severe guilt from having survived when so many others perished.

3. Somatization: peptic ulcers, colitis, cardiovascular problems, mental confusion and nightmares.

4. Anxiety, agitation, and often paranoid ideation.

5. Disruption of maturational development.

6. In the most severe cases, there were psychotic disturbances with delusional or semidelusional symptomatology (Williams, 1993, p.11).

Despite the fact that many experienced one or more symptoms of survivor syndrome, this did not prevent social functioning (Giberovitch, 1992b). Many Holocaust survivors have lived very productively as physicians, attorneys, professors, authors, psychologists, social workers, scientists, businessmen, and philanthropists. Data collected from 300 survivors, who attended the first gathering of Holocaust survivors in Washington, D.C. in 1983, concluded that, in terms of socioeconomic accomplishments in their new environment, the survivors actually exemplified successful adaptation (Kahana, Harel, Kahana, \& Rosner 1988). 
The past experiences of Jewish Holocaust survivors were unimaginable, which leads the researcher to wonder what it is like for these survivors today. Even the youngest of the survivors are fifty-five years old and older. They may be facing the problems of advancing age such as changes in their health status. Did the past experiences have an impact on the survivors' health care behaviors? The health care behaviors of Jewish Holocaust survivors should be explored and described so that nurses and other health care providers may be prepared to appropriately care for them.

\section{Problem Statement}

Fifty-five years after the Holocaust the scars are still present. "No one is ever really free from the Shoah [Hebrew word for annihilation]. There are simply too many reminders; sirens, uniforms, dogs. The right or wrong combination of triggers revives memories too difficult to bear" (Krell, 1992, p. 26). As the survivors continue to age, physical and perhaps emotional problems will require nursing care. Mental health nurses may be called upon to assist in the Holocaust survivor's adaptation to the normal problems of aging, such as grieving, loneliness, or isolation. In order to provide appropriate and competent care, an understanding of the survivor's experiences and special health care needs is required. Elie Wiesel, the famed Nobel laureate and Holocaust survivor himself, was asked by a physician "How do we treat the Holocaust patient?" His response was "Listen to them, listen very carefully. They have more to teach you, than you them" (Krell, 1992, p. 31).

\section{Research Purpose}

The purpose of this study was to explore and describe the lived experiences of Jewish Holocaust survivors seeking health care in the United States today. Understanding 
those experiences may direct the nurse in implementing creative and appropriate nursing interventions to provide comfort and to assist with the survivor's health care.

\section{Research Question}

The major research question was what is the experience of being a Jewish Holocaust survivor seeking health care in the United States today?

\section{Definition of Terms}

Holocaust - the mass slaughter of European civilians, especially Jews by the Nazis during World War II (Mish, 1998).

Jewish - of, pertaining to, or characteristic of the Jews (Flexner, 1989). Explaining what it means to be Jewish is complicated because it is more than a religion, it is a culture. All of the different denominations of Judaism: reform, conservative, orthodox, "Chasidic" (ultra - orthodox) and reconstructionist worship differently, although their basic tenets are similar. Culturally there are similar values, beliefs, folkways, foods, celebrations, and rituals despite the fact that many Jews have different countries of origin. Jews share a history as a minority subjected to persecution for most of their 5,758 years (Schwartz, 1995).

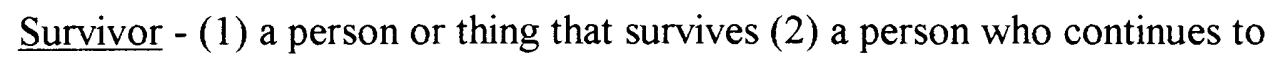
function or prosper in spite of opposition, hardship, or setbacks (Flexner, 1989). Significance of the Study

Historically, most nursing interventions were disease specific, similar to the medical model. Today, following the nursing model, interventions are based on human responses to health care needs. According to Leininger (1985), there are some nurse researchers who have been prepared in anthropology, philosophy, education, and history. 
"They are keenly aware that people are more than a cluster of cells, a body system, or a diagnostic case to be treated or understood from a narrow viewpoint" (p. 2). This perspective is even more true today. The trend in nursing is toward the delivery of holistic, humanistic, and culturally appropriate and competent care.

There were approximately 200,000 - 300,000 European Jews who survived the Holocaust (Williams, 1993). According to Jewish Family Services, it is estimated that 25,000 - 30,000 Jewish Holocaust survivors are now living in South Florida (H. Martin, personal communication, June 4, 1998). Nurses encounter Holocaust survivors as they seek help in various medical and mental health facilities. Nursing, therefore, needs to be cognizant of the uniqueness of the Jewish Holocaust survivor's experience and any special needs that they may have.

A search of the literature using the key words "Holocaust survivor" revealed that most articles were found in psychology, social work, and psychiatry; none were found in nursing journals. This study will add to nursing's body of knowledge with respect to cultural sensitivity and competence, holistic care, and humanistic care as it relates to Jewish Holocaust survivors.

\section{Researcher Assumptions}

The researcher's primary assumption is that the Jewish Holocaust survivors are active participants in seeking health care today. The researcher is also assuming that the data given by the participants is their perception of reality.

\section{$\underline{\text { Researcher Bias }}$}

As a clinical instructor in a nursing program, I was supervising a student who was doing her first accucheck on a diabetic patient. The procedure was carefully explained to 
the patient before the student began to select a site and dab it with alcohol. The finger stick elicited a resounding, agonizing scream from the patient. As my student and I stood pondering what seemed to be an inordinate response to a finger stick, a series of numbers tattooed on the woman's left forearm became visible to me. After calming the patient, I began to calm my understandably shaken student by explaining that the woman appears to be a Holocaust survivor and this finger stick may have prompted some unpleasant feelings. What memories, what fears, what horrors did this simple procedure trigger for this elderly Jewish woman? Although I am not a child of Holocaust survivors, some of my childhood friends were children of Jewish Holocaust survivors. I distinctly remember conversations with my mother about my friend's mother losing her entire family in the Holocaust. My brother-in-law is the child of two Jewish Holocaust survivors. He has shared many stories about his family's Holocaust experience with me. As a researcher, and as a nurse, I admit to feeling that the Holocaust experiences were traumatic, lifestressing events that probably have had profound and lasting effects on the survivors' functioning. 


\section{Review of the Literature}

This chapter reviews the literature related to Concentration Camp Syndrome, Post Traumatic Stress Disorder, physical and mental health problems, the child survivor, families of survivors, therapist's attitudes, coping, and personal descriptions of adaptation. Most of these studies are on those Holocaust survivors seeking help for medical or emotional problems. Fewer studies were done on survivors who were not seeking professional assistance and have, from most reports, made successful adaptations to their post-war lives (Kahana, Harel, Kahana, \& Rosner, 1988).

\section{Concentration Camp Syndrome}

Concentration camp, or Survivor Syndrome, as it was named by Neiderland in 1961 described the pervasive guilt of having survived the Nazi Holocaust when so many others perished. Included in this syndrome are depression, anxiety, somatic disorders, and in the most severe cases, psychotic disturbances (Williams, 1993). The survivor's experience is unimaginable. Even with very graphic depictions, most non-survivors cannot comprehend the extent of the suffering. Feeling that survivor guilt has not been sufficiently explained in the literature, Garwood (1996), a psychiatrist, drew upon his own experiences as a child survivor in an attempt to explain it. Garwood described what he thought to be the four elements of survivor guilt: powerlessness, annihilation anxiety, object loss, and torture. "All four reinforce each other but powerlessness in the face of annihilation threat is of the greatest importance" (p. 245). Prisoners were shot if they responded in any way to the sight of another prisoner being killed or tortured. This resulted in passivity and helplessness and a feeling of powerlessness. The author 
described how powerlessness in later life, as the Holocaust survivor became ill or aged, evoked unconscious memories of the earlier vulnerable state.

Bower (1994) was concerned with long-term psychiatric and sociological consequences of the death experience, and whether there was a difference between these consequences for those who survived as children and those who survived as adults? His sample was selected from a group of concentration camp survivors who made compensation claims to the German government. He studied this phenomenon by interviewing 96 survivors who were under 16 years of age, and 90 survivors who were over 20 years of age at the time of the liberation. During the interviews the majority of subjects "stated spontaneously that ultimately their survival was beyond their control and a matter of luck" (p. 392). Bower found that there was little difference in anxiety, somatization, and intellectual disturbances between the two age groups. There was a significant difference in the amount of aggressive, suspicious, explosive behavior and hypersensitivity in the two groups, with a far greater amount in the younger group.

Depression was significantly greater in the older group. The limitations of this study were not cited.

\section{Post Traumatic Stress Disorder in Holocaust Survivors}

Posttraumatic stress disorder (PTSD) has been described as the development of characteristic symptoms following exposure to an extremely traumatic stressor, involving actual or threatened death or serious injury (First, 1994). The person reacts to this experience with fear and helplessness, persistently relives the event, and tries to avoid being reminded of it. People reexperience the traumatic event in their dreams and daily thoughts. Determined to evade anything that would bring the event to mind, they undergo 
a numbing of responsiveness along with a state of hyper arousal. Other symptoms that were described included depression, anxiety, and cognitive difficulties such as poor concentration (Kaplan \& Sadock, 1998).

Previous studies have shown greater rates of depression in Holocaust survivors than in non-Holocaust survivors (Kahana et al.,1988). Yehuda, Kahana, Southwick, and Giller (1994) subdivided Holocaust survivors into survivors with PTSD and without PTSD. The purpose of the survey was to examine depressive features in patients with PTSD. Subjects were non-treatment seeking members of a Jewish community: 23 Holocaust survivors, 11 of whom had already been diagnosed with PTSD, 12 who had not. The mean score on the depressive scale was significantly higher in the PTSD group. Analysis of subscales such as self-criticism, dependency, and self-efficacy revealed selfcriticism to be significantly higher in the PTSD group with no significant difference in dependency and self-efficacy. "The self-criticism subscale describes an introjective, selfcritical or guilty type of depression characterized by intense feelings of inferiority, guilt, and worthlessness, and by a sense that one must struggle to compensate for having failed to live up to expectations and standards. .."(p. 703). The data from this study suggested that survivors with PTSD had more guilt-ridden depression compared to those without PTSD. The difficulty in reliably discriminating between different forms of guilt was considered a limitation of the study.

In another study by Yehuda et al. (1995b), 72 Holocaust survivors, 40 who had PTSD and 32 who did not, and 19 comparison subjects were surveyed to examine the relationships among cumulative lifetime trauma, recent stressful events, and the presence and severity of current PTSD. The results were that the 40 survivors with PTSD reported 
significantly greater cumulative trauma and recent stress than survivors without PTSD and the comparison subjects. The conclusion was that the presence and severity of current PTSD were related to stressful life events that were experienced after the Holocaust. A limitation of the study was that there might have been other personality factors that contributed to the presence of PTSD symptoms.

Yehuda et al. (1995a), in yet another study, hypothesized that changes in urinary cortisol are consistent with the idea that there is enhanced negative feedback regulation of cortisol in PTSD. These alterations reflect adaptation "that is different from the more traditionally described 'desensitization' or dysregulation, in which the hypothalamicpituitary-adrenal (HPA) axis becomes more sensitized after exposure to trauma" (p. 982).

The study included 47 Holocaust survivors who had been in concentration camps and 15 people who were not Holocaust survivors. All were comparable in height, weight, age, race, religion, and income. Urine was collected for twenty-four hours on each. It was found that Holocaust survivors with PTSD had significantly lower levels of urinary cortisol than survivors without PTSD and the group without Holocaust experience. No significant difference was found between the latter two groups. "It can safely be concluded that exposure to trauma per se is not associated with long-term cortisol abnormalities. Rather, neurobiological alterations in cortisol release are associated with current symptoms of a clinically significant nature" (p. 984). A limitation of the study was that the cortisol findings might have been confounded by the effects of the aging process on the subjects.

Yehuda et al. (1996) explored relationships among dissociation, trauma, and PTSD in elderly Holocaust survivors. A random sample of 60 Holocaust survivors was 
selected from a publicly available list. Although stress was not found to be a requirement for dissociation as it was with PTSD, there seemed to be an unusually high incidence of stressful life events among patients with dissociative disorders, suggesting that dissociation is a consequence of trauma. It appears that in certain traumatic events such as sexual abuse and persons victimized as children, the occurrence of dissociation is frequent (Yehuda et al., 1996). The findings supported prior observations that trauma survivors with PTSD displayed a higher degree of dissociation than trauma survivors without PTSD. One limitation of the study was that the dissociation scores might have been affected by the age of the subjects. Another limitation was that the length of time between the trauma and the dissociation survey might have contributed to the findings.

Yehuda et al. (1997) compared the symptoms of PTSD in 70 concentration camp survivors and 30 survivors who avoided imprisonment by living in hiding. Given the duration of the Holocaust, it was likely that individuals experienced numerous stressors. The results showed no significant differences between survivors in camps or survivors in hiding in the severity of any particular symptom. "From a therapeutic perspective, the failure to note differences in symptoms between the two groups of Holocaust survivors is also quite important because it serves to validate the experience of Holocaust survivors who were not in camps" (p. 459). The survivors who were not in camps often considered themselves lucky and not worthy of seeking attention for the sequelae of their experiences. The clinician needs to understand the many different types of traumatic events that can produce painful effects. A limitation was the fact that this was not a longitudinal study, therefore the symptoms described by the participants might have been different closer to the time of the trauma. 
Lichtenburg and Marcus (1994) described a case study of an 85-year-old male Holocaust survivor who had several hospitalizations over 15 years. He responded favorably to pharmacotherapy with haloperidol and chlorpromazine however, he stopped taking his medication against medical advice. According to his psychiatrists, considering the difficulty this man had with basic trust, a true therapeutic relationship was felt to be impossible. At the time of the most recent hospitalization, the attending psychiatrists attempted to provide a supportive environment where he would feel as little threatened as possible, in addition to restarting pharmacotherapy. When he felt sufficiently comfortable, he began to speak about his past experiences. Retelling the stories of dangers that he survived was believed to have helped him come to terms with his fears (Lichtenburg \& Marcus, 1994).

\section{Major Depression in a Holocaust Survivor}

Abromowitz, Lichtenberg, Marcus, and Shapira (1994) presented a case study of a 63-year-old female Holocaust survivor who was hospitalized for major depression and a suicide attempt. Ida, who was the sole survivor of her family at the age of 15 , did well for years, became a nurse, married, moved to Israel, and had three children. She was described by her children as energetic and optimistic, and made no mention of her Holocaust experience. She had no previous history of mental health problems. Apparently her only son married, adopted a very observant Jewish lifestyle, and distanced himself from the family during the year prior to his mother's hospitalization. This perceived sense of loss of a family member is particularly devastating to a Holocaust survivor. Ida displayed many features of survivor syndrome: guilt, anxiety, depression, 
and alexithymia, an impairment in the ability to express feelings and moods. She was placed on psychotropic medication and given 16 ECT treatments, showing minimal improvement. The decision made by her psychiatrist was to "strengthen her defenses by teaching her to cope with her anxiety" (p. 79). Her husband took a more active role in calming her and participating in relaxation exercises. This helped restore some cohesion to her ruptured sense of family. Supportive therapy helped her regain a measure of optimism.

\section{Gastrointestinal Disorders}

Many gastrointestinal disorders of nonorganic origin may be related to motor abnormalities that originate in the central nervous system. Stermer, Bar-Tur, and Levy (1991) surveyed 623 patients, which included 239 Holocaust survivors and 384 Jews who had left Eastern Europe before the Nazi occupation, with a mean age of 70 for both groups. The symptoms of GI disturbances that were investigated were abdominal pain, irregular bowel habits, diarrhea, constipation, abdominal distension, heartburn, flatulence, anorexia, tenesmus, aerophagia, nausea, vomiting, and mucus in the stool. Eight of the thirteen symptoms of GI disturbance appeared with statistically greater frequency in the Holocaust survivors than in the control group. Limitations of the study were not cited.

\section{Sleep Disturbances}

Rosen, Reynolds, Yeager, Houck, and Hurwitz (1991) hypothesized that Holocaust survivors would have more sleep disturbances than depressed or healthy subjects, and that the survivor's problems would be correlated with the amount of time spent in a concentration camp. Their survey sample included 42 survivors, 37 depressed patients, and 54 healthy subjects. All were given the Pittsburgh Sleep Quality Index, a 
self-rating instrument that inquires about quality, latency, efficiency, duration, interruptions of sleep, use of sleep medication, and daytime dysfunction. The results revealed that the Holocaust survivor group had significantly greater sleep impairment than the healthy group and less sleep impairment than the depressed group. Of the findings within the Holocaust group, sleep disturbances and frequency of nightmares were positively and significantly correlated with the duration of internment in concentration camps. One limitation noted was that none of the respondents were under twelve years old at the time of the Holocaust, suggesting that future studies needed to include this age group.

Sleep and dreaming disturbances are seen as the hallmark of long term effects of traumatic stress. These manifest in the form of increased latency in falling asleep, fragmented sleep, alterations in sleep cycle, or disturbed dreaming (Kaminer \& Lavie, 1991). Disturbed dreaming is characteristic of PTSD and "concentration camp syndrome" (p. 664). Kaminer and Lavie (1991) used a descriptive design to study 23 Holocaust survivors and 10 control subjects. The Holocaust group was divided into two groups: those who had successfully adapted to post-war life and those who had not, based on job performance, marital problems, social relations, somatic complaints, mental problems, and general dissatisfaction with life. The well-adjusted Holocaust survivor group had the lowest rate of dream recall. They had no recollection of dream content and some were unaware of having dreamt at all. "We would like to suggest that the decrease in dreaming in well-adjusted survivors serves as an adaptive protective mechanism against disturbing dreams. In order to prevent the surfacing of any anxiety-arousing memories from the past, dream recall was unconsciously altered in the well adjusted" (p. 668). A limitation 
noted by the authors was that it was difficult to ascertain whether the decrease in dreaming developed as a defense mechanism or whether it was dependent on the survivor's individual characteristics.

\section{The Holocaust Survivor with Cancer}

Baider, Peretz, and Kaplan De-Nour (1992) examined whether coping with a past life-threatening situation affected coping with new life-threatening situations such as cancer. The survey included 53 cancer patients who had survived the Holocaust and 53 cancer patients with no past life-threatening experiences. The time since the diagnosis had been made was similar for all subjects. According to the researchers cancer may be seen as a metaphor for the experience of the death camps. Both experiences might have been associated with fears of pain, disfigurement, and disability. Both experiences might also have been associated with uncertainty, loss of personal control, social rejection, and a sense of total helplessness. The Holocaust survivor group scored significantly higher on all subscales indicating psychological distress. In order to get more information as to whether Holocaust survivors were always high in psychological distress, the authors examined a group of Holocaust survivors who did not have cancer. This group was not found to be high in psychological distress, indicating that it seemed that the survivors with cancer were struggling more with the new life-threatening stressors. The conclusion was that Holocaust survivors or anyone who has had previous life threatening situations "should be regarded as a 'high risk' person" (p. 14). Baider et al. quoted a patient "Tell me how we can survive again?" (p. 14). The authors encouraged the planning and implementing of psychological interventions. A limitation noted by the authors was that 
the advanced age of the group studied might have affected the survivor's ability to integrate their traumatic past.

Baider, Peretz and Kaplan De-Nour found from their previous study that patients with severe past stress lacked the ability to mobilize a coping mechanism of adaptive denial in dealing with their new stress - cancer. To expand on their previous study Baider, Peretz and Kaplan De-Nour (1993) compared 57 cancer patients with Holocaust experience with 50 Holocaust survivors without cancer. Highly significant differences were found on all scales of the Brief Symptom Inventory (BSI) in the two groups except for depression. The study suggested to the researchers that the normalcy of " healthy" survivors is attributable to suppression and denial of many emotions, hostility in particular. They felt that these findings might be generalizable to the larger population of "victims" that remain psychologically vulnerable. This study reinforced the researchers' belief in psychological intervention. The researchers admitted that the limitation was the cross-sectional design. A longitudinal study might have better provided the answer to whether the survivors remained unable to mobilize defenses.

Peretz, Baider, Ever-Hadini and Kaplan De-Nour (1994) conducted another survey, using female subjects only, to test the hypothesis that extreme trauma from the past makes cancer patients more vulnerable and thus at higher risk for psychological distress. The four groups of women were Holocaust survivors with cancer, healthy Holocaust survivors, cancer patients without Holocaust experience, and healthy women with no Holocaust past. The Holocaust experience seemed to sensitize individuals, as indicated by their profound emotional distress, which was found to have been distinctly higher than their non-Holocaust counterparts with cancer. It was suggested that health 
care providers be alert to their patient's life history when a cancer diagnosis is made so that psychological evaluations can be included in the plans. Again, the cross-sectional design of this study was noted as a limitation.

\section{Child Survivors}

Of the millions of Jews who perished during the Holocaust approximately 1.5 million were children. Those who were not killed "suffered a more terrible fate than those who died" (Krell, 1985a, p. 378). Those who survived concealed themselves in every imaginable and unimaginable hiding place constantly in fear of being exposed. Even now the child survivors are described as preferring to remain invisible. It has been noted that child survivors have tried to belong, to cope and not be identified as different. Most of them have described themselves as chameleons adapting readily to changes in the environment (Krell, 1985a).

According to Krell (1993) most of his psychiatric colleagues agreed that the early childhood years were crucial to normal development and that disruptions, either major or minor, could have a lasting effect. This belief was based on the findings of previous studies that the differences in psychopathology did not relate to the nature or amount of persecution, rather to the age of the child at the time. It was believed that the youngest suffered the greatest. For most of the child survivors "their war did not end with the liberation" (p. 385). After the war, the child survivors received confirmation that they were orphans and that there was no home to which to return. Typically, a Jewish child lived in hiding with a Christian family and developed attachments to the sheltering family who treated them kindly. After the war, removing them from this family was a second major loss. They were placed in orphanages or in the home of relatives, who were 
bereaved and often preoccupied, and in entirely different countries. In contrast, the older survivor, while traumatized as well, had memories of a happy childhood, an education behind them, and a strong sense of Jewish identity and tradition.

Modai (1994), an Israeli psychiatrist, wrote a case report about a 58-year-old woman suffering from bipolar disorder. This woman was four years old when her father was arrested and then her mother. She was left alone with her grandmother who died just a few days later. When the child was found, she was taken to a monastery where she remained until the liberation of her parents from the concentration camps. The woman had total amnesia of her childhood. Any attempt to confront the unintended abandonment by her parents resulted in psychosis. The therapist felt that this amnesia was a defense mechanism against psychosis and that the memories were best left unexposed.

Tauber and Vanderhal (1997) looked at the perceptions of trauma in a case study of Deborah, a Holocaust survivor who was eight years old when her mother was taken away. Her mother's parting wish was that Deborah look after her younger brother. She devoted her life to overprotecting him until he finally rebelled. There was no one after the war, no loving parent figure, to help modify her understanding of her mother's wishes. Most of these child Holocaust survivors have been described as having no one to explain their traumas to them. They developed compound personalities: part child frozen at the age of their trauma and part adult who functioned age appropriately. On one end of the continuum were those who effectively acted like a gentle parent explaining to the inner child what had happened to them. This group usually fared very well. On the other end was the clinical population who needed help in transforming their perceptions of trauma. 
Robinson, Rapaport-Bar-Sever, and Rapaport (1994) in a correlational study, surveyed 103 child survivors to determine whether the forms of persecution affected the state of the survivors. The 103 participating survivors were divided into four groups: death camp survivors, labor camp survivors, those who had survived in hiding, and children of partisans. They also studied the correlation between the age at the time of persecution and psychological adjustments. The results were that there was a significantly high relationship between death camp survivors and suffering, suggesting the correlation between the intensity of trauma and the after effects. Depression and anhedonia [the inability to feel pleasure] were more pronounced in this group. The youngest children persecuted were found to be the most disturbed. Of the 103 child survivors, 66 had one or both parents survive as well. The children whose parents survived described less persecution. Limitations of the study were not cited. Therapist's Attitudes towards Holocaust Survivors

Weiss and Durst (1994) suggested that the details of the trauma and individual means of survival make up the survivor's post-traumatic personality and determine to a great extent reactions to therapy. The two therapists described survivors as having serious trust issues that may initially cause them to reject the therapist's offer of help, or to express aggression toward the therapist. The authors stated that in many cases, it was difficult for the therapist to listen to stories of horror without experiencing the trauma himself.

The term conspiracy of silence was used to describe the reactions and attitudes of society towards hearing about the Holocaust (Danieli, 1988). According to Danieli, it was Neiderland, in 1964, who described the tendency of therapists to "gloss over" (p. 220) 
the Holocaust experience because they did not wish to face the horrors. This was the basis for Danieli's phenomenological study of 61 psychotherapists. Within this group were 28 social workers, 23 psychologists, and 10 psychiatrists all with four to forty years of experience. The dominant themes reported were countertransference phenomena, bystander's guilt, rage, dread, horror, grief, mourning, and shame. Danieli described the shame that the therapists felt as caused by what he called "the 4th narcissistic blow" ( $p$. 229). Danieli referred to Freud's Complete Works in which Freud speculated about the reasons why people rejected psychoanalysis. Freud described the first blow as being cosmological, when Copernicus declared that the earth was not the center of the universe. The second blow was biological, when Darwin proclaimed that man evolved from the ape. Freud, himself, was responsible for what he called the third blow, which was psychological, when he theorized, "the ego is not even master in its own house" (p. 229), that there are limits to consciousness. Danieli believed that "Germany gave humanity the fourth blow, by shattering our naive belief that the world we live in is a just place in which human life is of value, to be protected and respected" (p.229).

\section{Holocaust Survivors Entering Nursing Homes}

Entering a nursing home can be a difficult experience for anyone. The elderly are forced to confront their own mortality as most view this as their last residence before death. For the concentration camp survivor, this is not the first time that they have had to go to a strange place that might have represented imminent death. The Holocaust survivor will thus have an even more difficult transition because "institutionalization represents loss, change of status, separation, and possibly abandonment which all recall their earlier trauma and produce a sense of loss of personal control' (Adams et al., 1994, p. 101). 
Adams et al. (1994) described five case studies that point out the importance of understanding each person within the context of their own history. The authors stated that giving the aging survivor choices, and allowing them to be part of the planning process for their care contributed to a sense of well being.

\section{Taping Holocaust Survivor's Stories}

Krell (1985b) started taping eyewitness accounts of Holocaust Survivors in Canada in 1980. The taping projects were initiated for historical and educational purposes because they conveyed amazing stories of adaptation and coping under extreme stress. Twenty-one Canadians who were child survivors were interviewed. Most of them had an acute awareness of what helped them to survive physically and emotionally. They described their ability to sense change and respond readily to new situations. After the taping, the survivors were asked if they felt better or worse. Most responded that speaking about their experiences gave them a sense of personal well being and a sense of closure.

\section{Transgenerational Effects of the Holocaust}

Since the mid-1960s, researchers have shown considerable interest in the children of Holocaust survivors who are now all adults. The thrust of the literature is on the impact of the parent's trauma on the second and third generations (Steinitz, 1992). A fellow child survivor, friend, and colleague of Steinitz maintained that "being heirs to the Holocaust helped the second generation in the development of their own identity, imbuing them with a special sensitivity to human suffering, and with a sense of direction and meaning to their lives" (p.79). 
Safford (1995) theorized that the children of survivors might have guilt for not being able to undo the Holocaust experience. Some survivors married in haste after the war to assuage their intense grief. The couple, for whom love may not have been the basis for the union, focused on the children. These cherished children represented restoration, justification for survival, and a hope for meaning. "These overwhelming expectations created a need in many of the second generation to make up for their parent's deprivation, leading to frustration and guilt since the task is unrealistic" (p.136). Many support groups for children of survivors have been created for sharing feelings about their painful legacy.

Wardi (1994) in case studies of two families described the impact of the Holocaust on intergenerational relations. The boundaries of the parent-child relationship were challenged since the survivors experienced such brutal losses during the Holocaust, separation and loss were especially difficult for them. The children represented their parent's reason for existing. The parents tended to be overprotective and reluctant to give their children independence. The children shared their parent's pain and loss and also found separating difficult.

Major (1996) investigated whether the children of Norwegian born Jewish concentration camp survivors suffered from "second generation syndrome" or other psychological disturbances of adolescence. Major interviewed five concentration camp survivors and their 19 children, and the comparison group of 18 Norwegian born Jews, who fled to Sweden before the war, and their 37 children. The author described that the children of the Holocaust survivors held the view that their parents' concentration camp experience influenced their life in a problematic way. The relatively small number was 
cited as a limitation that should be considered before generalizing the findings to the larger population of children of survivors of trauma.

After a review of the literature, Magids (1998) felt that there was a tendency to over generalize the consequences of the different Holocaust experiences. The author felt that the differences between the children of those who survived concentration camps and the children of individuals who survived by living in hiding were disregarded. Her study included 50 participants who were the children of survivors and 50 who were not Holocaust survivors. She concluded from her interviews that although there were marked differences in the psychological functioning of children of concentration camp and "hidden" parents, the children were not more psychologically impaired than the children from the non-traumatized parents. A limitation of the study that might have affected the results is that the participants in the children of survivors group were more psychologically healthy and more highly educated than the control group.

Schwartz, Dohrenwend, and Levav (1994) focused on the theory that the offspring of parents with depressive and anxiety reactions, as in the case of Holocaust survivors, have higher rates of psychiatric disorders than in the offspring of parents who do not. The sample population consisted of 147 in the children of survivors group and 476 in the control group who were given self-report questionnaires. The results indicated that there were no significant differences in the children of Holocaust survivors than in the control group. The mean scores on demoralization and enervation were the same and there were no significant differences in post-traumatic stress symptoms. A limitation that was noted by the authors was the large decrease in the number of genetically vulnerable people who survived the camps. The authors also admitted to the possibility that the 
respondents were at a developmental stage where the rates of psychiatric disorders were low. A longitudinal study might have resulted in different findings.

Sorscher and Cohen (1997) studied how Holocaust parents' traumatic experiences affected the children's ethnic identity. Forty children of Jewish survivors and 38 Jewish children of non-survivors were surveyed. The results of the study described that the children of Holocaust survivors had a high level of Holocaust related imagery, however there was no significant difference between Jewish identity in either group. A limitation of the study cited was the shortage of reliable instruments for measuring ethnic identity. A second was that the generalizability of the results might have been compromised by the fact that the sample population was self-selected.

\section{Coping and Adaptation}

During the Holocaust, coping was in response to unrelenting limitless stress: starvation, torture, beatings, loss of loved ones, and the constant threat of death (Kahana, Kahana, Harel, \& Rosner, 1988). Kahana, et al. suggested that there were at least two experiential phases. In the initial phase of shock and disbelief the individual protected himself by blocking the enormity of the threat through denial. In the second phase, there were a number of individual responses such as emotional numbing, selective perception, identification with the aggressor, forming friendships, and exercising a will to live (Kahana, Kahana, Harel, \& Rosner, 1988). "One difference between those who drowned and those who survived may be the ability to move beyond the state of collapse or immobilization and marshal their resources toward some form of active mastery" (p. 65). It is important to note that even the strongest at active mastery may have perished as a 
result of the sometime randomness of the selection process in the death camps. Usually, those selected to live were thought to be useful, in some way, to the Nazis.

Fenig and Levav (1991) questioned how to account for the resilience demonstrated by those who were exposed to such devastating trauma. They used the theory of social support as a framework to determine the buffering effects of social support on stressful life events. They interviewed 145 Holocaust survivors from Poland who were 15 to 20 years old at the time of their internment. Demoralization, a construct defined as a state in which an individual sees no outlet, was explored using a 27 -item Demoralization Scale. The results were higher demoralization scores measured in individuals with more brutal experiences and lower demoralization scores in those who had contemporary social supports. A limitation cited by the authors was that all of the respondents had living spouses at the time of the survey, which might have contributed to lowering the demoralization scores.

The Gulf War created a state of emergency unlike anything else in Israel's history because of it's proximity to the civilian population. Uncertainty about where the Iraqi missiles would land and the threat of gas warfare necessitated confinement to shelters and the distribution of gas masks to the entire population. Hantman, Solomon, and Prager (1994) studied the Holocaust survivors, who comprised $10 \%$ of the elderly population living in what they called civil defense "area A", to see if they would have better coping skills as a result of their previous trauma, or impaired coping. A convenience sample of 192 subjects was selected based on two criteria: age and location. The age requirement was greater than 60 for females, and greater than 65 for males. Civil defense "area A", had the highest risk of being hit by Iraqi missiles. The findings revealed that those who 
had experienced more severe trauma in World War II demonstrated the highest level of vulnerability. This did not support the theory that exposure to prior stress has an inoculating effect on an individual's ability to cope with subsequent stress. The findings supported the theory that with regard to the post-traumatic adaptation of Holocaust survivors, there is an enduring response of perceived threat in the environment. The limitations of the study were not cited.

Yeheskel (1995) studied the coping ability of 20 Holocaust survivors, 10 men and 10 women, using both qualitative and quantitative methods. She found that the interviews centered around three main themes: (a) the intimate environment, many spoke about having a confidant or someone they could go to with problems; (b) meaningful major activities, their perception of the importance of their primary activity or role; and (c) the extent to which their post-war environment allowed appropriate developmental tasks. In the quantitative portion, a Sense of Coherence instrument was employed. The results showed a more significant correlation between meaningful major activities and sense of coherence than the other life issues mentioned. The research was limited by the small sample size. The retrospective nature of the data, which was unavoidable, was also cited as a limitation of the study.

In case studies of two female Holocaust survivors with Post Traumatic Stress Disorder, Salamon (1994) found denial and acceptance to be the coping and defense mechanisms. In Mrs S., even partial acceptance of her trauma gave her the opportunity to work through some of her emotional consequences. Mrs B. avoided any stimuli that might have caused her to reexperience the trauma. She had almost constant periods of hypervigilence and occasional angry outbursts. Although denial is an immature defense 
mechanism, it was effective for some survivors. Those who had more mature coping mechanisms, such as acceptance, seemed to suffer less (Salamon, 1994).

Another case study of Mrs M.S., a 92-year-old Holocaust survivor, illustrated an amazing and inspirational picture of mental health (Bar-Tur \& Levy-Shiff, 1994).

Mrs M.S. maintained her high level of mental wellness by frequently "witnessing" her experiences. The authors emphasized that in addition to justifying her own survival, and helping her find some meaning in her horrifying past, it gave her a sense of mastery and control over her existence.

Lee (1988), a psychotherapist and Holocaust survivor herself, found that most of the literature focused on the psychological problems and weaknesses. She explored the strengths of survivors. From previous studies, Lee had concluded that teenage survivors had inner psychic strength, which had been cultivated in early childhood, that enabled them to overcome the horror of incarceration and function successfully after the war. She felt that not enough was known about the reasons why she, and others like her lead fulfilling lives, which prompted her study of 124 Holocaust survivors. Her hypothesis was that "those who survived, on the average, might have possessed certain resources and strength in part from fortunate childhood nurturing, that afforded them an edge over many who did not survive" (p. 77). Personal interviews were conducted using a 36-item questionnaire about early childhood experiences, concentration camp experiences, and about the lives they established after the liberation. The results suggested that the survivors had loving and nurturing childhood experiences. Limitations cited included a suggestion that the memories were from decades earlier and that the participants might have idealized their childhood experiences that occurred before the war. 
Rotenberg (1985), a psychiatrist and also a Holocaust survivor, divulged that when he arrived in Canada in 1948, his desire was to distance himself from the wartime experience. He was an overachiever, who by the age of 13 spoke nine languages fluently, even though his formal education didn't begin until age 10. He entered psychoanalysis as it was required in his psychiatric training. He had a transference with his therapist and through this rediscovered his father. He was the youngest of five children, much younger than his other siblings. He recollected his father, a Rabbi, as being very warm and nurturing, who allowed him to follow him everywhere. Rotenberg asked himself the question, "Why am I less neurotic than I might have expected to be?" (p. 387). He attributed his emotional stability to having been loved and made to feel special. Since he was so much younger than his sisters, he was doted on like having a second set of parents. "I was the child who would fulfill the hopes of the family for a great scholar" ( $p$. 388). This sense of specialness, which he described as narcissism without grandiosity, made him feel that he would survive, which he did on many levels.

Frankl (1963), in one of the classics of Holocaust literature, described his adjustment to camp life; the emotional numbing to the sight of dead bodies, enduring hard labor on starvation rations, and constant threats to his own life by escaping into a spiritual world. He could summon the image of his wife and have conversations with her. He spoke of sensitive people, intellectuals, who were more frail physically but less damaged spiritually. "They were able to retreat from their terrible surroundings to a life of inner riches and spiritual freedom. Only in this way can one explain the apparent paradox that some prisoners of a less hardy make-up often seemed to survive camp life better than did those of a more robust nature" (Frankl, 1963, p. 56-57). 


\section{Summary}

In conclusion, there is no shortage of literature on Holocaust survivors and their families as documented by social workers, psychologists, and psychiatrists. There seems to be many contradictions: they trust, they don't trust, they suffer, they cope, they have strengths, they have weaknesses, they feel isolated, they have a sense of coherence, they have numerous psychological problems, they have tremendous financial successes and academic accomplishments. The aging Holocaust survivors are interesting and complex in their methods of coping with the past and present day-to-day living. One of the gaps in the literature is related to how the survivors manage a crucial aspect of their lives, their health care. How the Holocaust survivors experience, interpret, and seek health care, within the context of their Holocaust experience, and how nursing can assist with these initiatives necessitates exploration. 
Chapter III

\section{Methodology}

This chapter discusses the research design, sample, procedure for data collection, method of data analysis, and bracketing of the researcher's assumptions and biases. This chapter also includes an in depth description of the protection of human subjects.

\section{Design}

The design for this study was a descriptive, qualitative, and phenomenological study of the lived experience of Jewish Holocaust survivors seeking health care in the United States today. Qualitative refers to the method of collecting and analyzing characteristics and meanings of this specific phenomenon. The choice of phenomenological method is guided by the appropriateness of the method to the phenomenon of interest. The goal of phenomenological research is to describe the lived experience and understand the meanings that this experience holds for the individual or group being examined. The underpinnings of phenomenological research are rooted in the existential philosophy that it is the lived experience that gives meaning to the individual's perception of a particular phenomenon. This perception of what is true or real for the individual is influenced by everything in his internal and external environment (Streubert \& Carpenter, 1995).

There are many different approaches to phenomenological data analysis.

Colaizzi's method of data analysis was influenced by the existential philosophy of Heidegger, one of the leaders of the Germanic phenomenological movement. With this method of description the researcher rigorously "tries to sustain contact with the experience as it is given" (Colaizzi, 1978, p. 53). Colaizzi quotes Heidegger "to let that 
which shows itself be seen from itself in the very way in which it shows itself from itself" (Colaizzi, 1978, p. 53).

Phenomenology seeks to describe the human experience, in a way that is free from presuppositions, as much as possible (Valle \& King, 1978). The researcher acknowledges the effects of his own experience with the phenomenon in order for the investigation to proceed objectively (Colaizzi, 1978). Objectivity is what Colaizzi refers to as "fidelity to phenomena" $(1978$, p. 52). Objectivity requires the researcher to recognize and affirm his own experience. This is accomplished through bracketing of the researcher's assumptions and biases.

\section{Bracketing of Researcher's Assumptions and Biases}

In order to conduct phenomenological research, the researcher's assumptions and biases must be bracketed so that personal beliefs or feelings about the phenomenon do not interfere with the researcher's interpretation of the data (Streubert \& Carpenter, 1995). This involves putting aside personal feelings and remaining open to the experience as the subject tells it. According to Colaizzi, objectivity requires the researcher to affirm his own experience, while respectfully "listening to what the phenomenon speaks of itself" (Colaizzi, 1978, p. 52). In an attempt to do this, a diary was kept of the researcher's feelings before and during the data collection process and while interpreting the data. Consistent use of bracketing helps to ensure "trustworthiness" of the data analysis (Streubert \& Carpenter, 1995, p. 46).

$\underline{\text { Sample }}$

The sample was a purposeful selection of seven Jewish survivors of the Holocaust who were prisoners in Nazi concentration camps during World War II, and who have had 
health care experiences in the United States. Inclusion criteria for the study were English speaking, Jewish men and women, who now reside in South Florida, and were willing to be interviewed. Excluded from the study were individuals with known neurological deficits, known psychiatric disorders, or known unstable medical conditions, such as unstable angina or unstable hypertension. Also excluded were survivors who had demonstrated severe emotional upset when previously speaking about their Holocaust experience.The participants were referred by the Holocaust documentation center at Florida International University.

\section{Protection of Human Subjects}

Before any subjects were contacted, the research proposal was reviewed by the Research Review Committee at Florida International University (Appendix A). The foremost consideration of the Research Review Committee and the researcher was to bring no harm to the study participants. If the Holocaust survivor seemed reticent, he/she was not encouraged to speak. If the questioning had caused any emotional distress, the session would have been terminated, and a referral would have been made to a therapist at Jewish Family Services for psychological support and counseling. The participants did not exhibit any signs of emotional distress during the interviews.

The participants had the right to self-determination. The subjects were informed that they had the right to decline participation in the study, or withdraw from the study at any time without any penalty. There was no coercion of any type to gain participation, and there was no financial remuneration offered.

The survivors were guaranteed freedom from exploitation. The participants in the study were assured that information revealed during the interview would never be used 
against them in any way.

The subjects had the right to expect that all data would be kept in the strictest confidence. The individual's names were excluded from all audiotapes and printed material. The taped interviews were identified by fictitious names. Numerical identification would be especially inappropriate for this population. Part of the dehumanization of their Holocaust experience was being identified by a number, which was usually permanently affixed on their forearm. All identifying information, tapes, and transcripts will be kept in a locked file accessible to the researcher only, for a period of three years, after which they will be appropriately destroyed.

The potential benefits to the survivors themselves, and to the extended population of Holocaust survivors far outweighed the risks. The benefits to the subjects were that sharing their experience helps give meaning to their life (Frankl, 1963), and serves to commemorate their loved ones who perished in the Holocaust. There was a risk that emotional distress might have occurred as the survivor related their experiences, however this did not occur.

The study participants had the right to full disclosure. At the time when the consent was signed, the researcher described the nature of the study, as well as the risks and benefits. The subjects had the right to ask for explanation of aspects of the study and study results at any time. Informed consent was documented by having a consent form signed (Appendix B).

\section{Procedure for Data Collection}

A letter was sent to the director of the Holocaust Documentation Center at Florida International University telling of the research purpose and asking for the names of 
prospective volunteer participants (Appendix C). The center then sought permission from these individuals to release their names to the researcher. After approval from the Florida International University Research Review Committee was granted (Appendix D), the prospective participants were contacted by telephone by the researcher. After verification that inclusion criteria had been met, and verbal consent had been given, a date and time was set to meet at a setting of their choice.

The meeting began with a "warming up" period of introductions. The consent form was read by the prospective participants and signed before the interview began. The interview consisted of the following open ended questions:

1. What is the experience of being a Jewish Holocaust survivor seeking health care in the United States today?

2. How can the nurse support you in meeting your health care needs?

The questions and responses were audiotaped. The audiotapes were coded using fictitious names in alphabetical order, such as Aaron, Barbara, Charles, etc. Notes were written by the researcher of any gestures or facial expressions that seemed descriptive of the phenomenon. The interviews lasted approximately two hours. If the interviewee became tired, and could not complete the session, an appointment would have been made to meet again at another time and place that was mutually convenient. This did not happen. Demographic information was collected including age, sex, marital status, number of children, and birthplace.

The audiotapes, which do not divulge the participant's identity, were given to a medical transcriptionist, personally known to the researcher, for typing. The transcriptionist was instructed to type the interviews exactly as heard on the tapes. After 
typing, all of the audiotapes, computer discs, and printed copies of the interviews were returned to the researcher.

Method of Data Analysis

Colaizzi's method of phenomonological analysis (1978) was used. This was a reductionistic process of content analysis with the end result being an exhaustive description of the essence of the Holocaust survivor's experience as it related to their health care needs. The essence is the most basic unit of common understanding of a phenomenon (Streubert \& Carpenter,1995). After audio taping the subject's description of the phenomenon, and transcribing the tapes, Colaizzi's procedural steps were as follows:

1. Reading the transcripts in their entirety to acquire a feeling for them.

2. Returning to the transcripts and extracting significant statements that pertained to the phenomenon being explored.

3. Trying to spell out the meaning of each significant statement. The researcher uses creative insight to go from what the data says to what the data means.

4. Organizing the formulated meanings from step three into clusters of themes.

5. The results of the previous steps are integrated into an exhaustive description.

6. The researcher returns to the participants for validation of the description.

7. If new data are revealed during the validations, incorporating them into the exhaustive description (Colaizzi, 1978). 


\section{Chapter IV}

\section{$\underline{\text { Results }}$}

This chapter presents the analysis of the transcriptions from seven interviews.

There were 62 significant statements related to the participant's health care experience.

The data was analysed using Coliazzi's approach to phenomenological research to determine the essence of the Jewish Holocaust survivor's experience with health care in the United States today. This chapter describes the results of the data analysis.

\section{Demographic Data}

The study participants consisted of four male and three female Jewish concentration camp survivors. Their ages ranged from 69 to 80 years old. Six of the seven participants were born in Poland, one was born in Czechoslavakia. Six of the seven were married, one was widowed a few years ago. Six of the seven participants have two to four children. One participant has no children (see Table 1).

Table 1

Demographic Data of Jewish Holocaust Survivors

\begin{tabular}{lcclc}
\hline Age & Gender & Birthplace & Marital Status & Children \\
\hline 7 participants & 4 male & 6 born in & 6 married & 6 have \\
age range: & 3 female & Poland & 1 widowed & children \\
oldest -80 & & 1 born in & & 1 has \\
youngest -69 & Czechoslovakia & no children \\
& & & \\
\end{tabular}




\section{Data Analysis Using Colaizzi's Method}

The researcher began by reading the transcriptions in their entirety several times. After reading them it became apparent that the interviews shared many common themes. Significant statements related to the phenomenon of interest were extracted and studied for meaning. The formulated meanings were organized into theme clusters. An exhaustive description of the findings of each theme cluster was written. Four of the seven participants were reached by telephone for validation of the findings to ensure the "trustworthiness" of the data analysis (Streubert \& Carpenter, 1995, p. 46). The researcher summarized the findings and asked, "Does it sound as if your experience has been described accurately?" Their responses were "Yes," "it sounds wonderful," "very good," and "I would love a copy of your paper." The researcher also asked, "Is there anything you would like to add?" Most of them responded "no." One participant began to repeat some of the same descriptions from the original interview. No new information was revealed at this time. The following paragraphs contain the significant statements, the formulated meanings, the theme clusters, and the essence of the experience of being a Jewish Holocaust survivor seeking health care in the United States today. Figure 1 demonstrates the data analysis process (p. 57-58).

Theme 1-Hiding and Avoiding

This theme was derived from descriptions of the participant's hiding illness while in the concentration camps. As prisoners, their thinking was that they needed to appear healthy and able to work to survive the selection process for the gas chambers. They needed to avoid the health care system in the concentration camps because this often meant being an involuntary participant in unusual experimentation, or the certainty of 
death (S. Friedman, personal communication, December 18, 1999). These behaviors,

learned during the Holocaust, have been carried with them throughout their lives. Many

Holocaust survivors continue to prefer hiding illness and avoiding the health care system as described in the significant statements.

\section{Significant Statements}

In the following passage Barbara described her attempt to hide illness and avoid

the health care system in the concentration camp.

My feet were swollen, very swollen, in Auschwitz, because the shoes didn't fit, and we had to walk ... I had a friend, a doctor in the infirmary, and she told me to "Come into the infirmary, after hours, in the evening, so that I don't have to put you down as a patient, and I will put some salve on your feet," because I had sores. A sore at Auschwitz, this was a death sentence. Whenever they had selections, a tiny sore and you were sent to the gas chamber, and my feet had big sores on the heels, so I came there and she put some salve on my feet and she bandaged them. As she finished, the door opened and in walked Dr. Mengela, and Dr. Mengela never looked at us, he looked past us, so I wasn't sure if he saw me, it was my wishful thinking that maybe he didn't see me, so I started inching toward the door to get out of there, and he turned around, pointed to me with his finger, and showed me with his finger to come back, to return, so he pointed to my foot and said "up, up, up," to lift my foot, so I lifted my foot. He turned to the doctor and said, "What's the matter?" The doctor said "Nothing," she was scared, "Nothing that a couple days medication won't heal. I put some medication on her feet," and Dr. Mengela said in German "Two days rest in barracks." If I hadn't had this doctor witness that she heard him say that, nobody would have believed me. I don't know anybody who met Dr. Mengela, eye-to-eye like this, and survived. He must have had some kind of special day.

The following significant statements described several of the participants continuing to avoid health care today. Barbara stated "This is a problem I had from the beginning, after the liberation, hiding from doctors and hiding from medical support or care." She also described:

I had a nervous breakdown in 1980. The nervous breakdown was in connection with my changes [menopause]. I did not seek psychiatric help, which I should 
have. My husband did not understand the value of it, I did, but as long as I wasn't pushed into it, I didn't do it.

Eve described, "I have a great, great problem with confiding in doctors in any matter. I avoid them like the plague. It is over two years that I saw my doctor last." She also stated "I understand English, and I can ask a question, but sometimes I am reluctant to ask questions."

Doris stated, "I try not to go to the hospital. I can go to a doctor for checkups, but I try not ."

Barbara described avoiding medication in the concentration camp.

Very often they [the Nazis] were inoculating us. They were putting something into our arms which we were sucking out and spitting out, we never knew if we got it, or not, and we were always afraid that this might be something poison or whatever. I still don't know what it was, and for what purpose we were given this.

Avoiding medication is a behavior that is continued today, as described by Eve:

At one point, the doctor used to tell me that I should take hormone replacement, and for some reason, I was scared to take hormones. I have a cousin, who died of breast cancer, and I know that hormone replacement therapy is probably important, but I don't do it.

Doris described something similar in her statement "I went to my husband's doctor, and I liked him ... and the doctor said I should change to take these hormones. . and I always, somehow, stayed away from it." She also stated "I do, from the war, have problems with the neck ... so I have a little problem here. I quess I'm getting older. I take nothing for it. My mother told me try not to take anything, if you can manage."

Charles described the Holocaust survivor's preference for avoiding institutionalization in a nursing home, which to some was reminiscent of the concentration camp experience. "The major point is that survivors, as a whole, generally, 
do not like to wind up in a nursing home. Nursing homes, usually, in our minds, are connected with institutions, which we have gone through, the experience, many times." Barbara described her preference for avoiding hospitalization "I have not been in the hospital in America. Then again, I avoid it. . when I have a problem I try to prevent it by self medicating"

\section{Formulated Meanings}

The significant statements described the participants hiding illness, avoiding medical care, avoiding taking medication, and avoiding institutionalization.

\section{Theme Cluster}

The previous formulated meanings were synthesized into the theme cluster of Hiding and Avoiding.

\section{Exhaustive Description}

Barbara related in her story about the sores on her feet "a tiny sore and you were sent to the gas chamber," which was the reason she wished to avoid being seen by Dr. Mengela. She had not heard of any prisoner who had met with Dr. Mengela and survived. The participants described that they still preferred to avoid health care. One mentioned that she "avoids doctors like the plague." Several stated that they recognized the need for taking medication, and yet, they preferred to avoid it. One participant spoke for many survivors as he described their desire to avoid institutionalization in nursing homes. The descriptions of this theme were hiding illness and avoiding the health care system (see Figure 1, p. 58).

The researcher was given the following additional information from a friend, whose parents are Holocaust survivors. "My mother still pinches her cheeks when going 
to the doctor's office. When the doctor asks how she feels, her response is always 'fine.'

She never admits to feeling poorly." This is an example of an elderly Jewish Holocaust survivor, who still preferred hiding illness.

\section{Theme 2 - Self Care}

In their attempt to hide illness and avoid the health care system, as described in Theme 1, the participants needed to rely on self care measures. In the concentration camps, self care meant meager attempts to cover up illness with whatever means they had at their disposal. Self care measures today, are more sophisticated means of staying well and avoiding the health care system.

\section{Significant statements}

All of the significant statements related to self care were described by female participants only. In the two following significant statements Eve and Barbara described self care attempts while in the concentration camps.

I looked sick. I had typhus or typhoid there in Auschwitz. I had a very high fever and I was like delirious. I remember that I couldn't stand up straight during this period when they made us stand for hours and hours to be counted. I remember I couldn't stand so my sisters like propped me up. They used to pinch my face and stuff me with paper so I would look a little bit more alive.

The only way out of Auschwitz was death. We were hoping some miracle would take us out of there. They came to look for able bodied people to work in German factories. We were standing erect and we were pinching our cheeks to look healthy, you know, and I was chosen, we were 20 girls and we were taken to a factory.

In the period immediately following the liberation of the prisoners from the concentration camps, many survivors died from the richness and abundance of food to which their bodies were no longer accustomed (Williams, 1993). In the following passage Barbara described her self care instincts during this period. 
After the liberation, the Swedish Red Cross, they looked like angels, the only thing is they didn't know that when the people were getting the food, they shouldn't be getting so much. The people grabbed this food and lined up around railroad tracks, they squatted, they were eating and it was coming out. . . and I stood there, and I looked at it and thought, oh my God, what are they doing, why are they doing that? That was when they started dying, and thank God that I didn't eat it.

The remaining significant statements related to self care described measures taken by the participants of this study today. Doris stated, "When I feel nervous I get pressure here (shoulders) and in the neck. On Wednesdays I do yoga. . I I do massage and whatever." She stated that "Nobody eats as healthy as me. This fibroid that I had sort of disappeared. . maybe because of my diet." She also added

I should mention that I have osteoporosis. I couldn't believe, when they took the test, that I had it. From all the people. I exercise, and I have skim milk, and I have tofu and green salads. I know and I watch.

Barbara had several descriptions of self care measures. "I have high blood pressure, but I have a machine in the house and I take my own blood pressure. I do take medicine for it and I try to keep healthy."

I survived every little thing, when I had all kinds of infections and all kinds of things, I worked myself through it. I had at one point a kidney problem. I was urinating blood and it was like knives cutting me. . so I worked on myself just like I did in the camps.

When I have a problem, I try to prevent it by self-medicating. I do a hypnotic thing, I know that if I don't feel good to breathe deeply, to relax, and to drink water. I do all kinds of magic things.

Eve described, "I have arthritis. I have rheumatism have back pain. I try to be a bit careful what I do and what I eat. I walk a little bit." 


\section{Formulated meanings}

The significant statements all reflected self care then (in the concentration camps) and self care now.

\section{Theme cluster}

The formulated meanings were synthesized into the theme of Self Care.

\section{Exhaustive description}

Self care, for the survivors, during the Holocaust, meant doing whatever they could to appear well. The prevailing thought was that if they were healthy, and able to work, they might escape selection for the gas chamber. They pinched their cheeks and stuffed their clothes to make them look well. Self care today, was described by all of the female participants in the form of eating healthy foods, exercising, relaxing, and even self hypnosis. In doing these things they hoped to prevent the need for medication and hospitalization, and it gave them a sense of personal control (see Figure 1, p. 58).

The researcher was given the following additional information by a relative, who is a Holocaust survivor. It describes self care in a concentration camp.

I was in the camps with my sister. I was 14 years old. Another girl there, who was 14 also, had no one, so we adopted her. One day while we were working on the railroad tracks, a guard, who was having fun, shot this girl. When she fell I bent over to catch her. We were always warned not to respond at all if someone was shot. The guard shot me in this leg. The bullet went all the way through. We knew better than to go to the clinic, so we packed the wound with snow to stop the bleeding.

\section{Theme 3 - Fear/Trust Dichotomy}

This theme was derived from the participants' descriptions of seeking health care, when necessary, with feelings of both trust and fear. Their significant statements described the connection with their health care providers. This connection gave them the 
assurance that the provider was a person who could be trusted. Even though the participants described a trusting relationship with their physician, they described fearfulness when visiting the physician's office. They also described skepticism and hesitancy in complying with a new medication regime.

\section{$\underline{\text { Significant statements }}$}

In the following significant statement Doris described general mistrust.

I think that maybe we are a little suspicious. . . we don't trust people too much, maybe. I don't just not trust doctors, but everybody, like if anyone calls and wants some information, on the telephone, even with you, when you called, at first I didn't want to do it. Then I thought it over, after I spoke to you. Maybe that's because I remember like so many times they were telling lies, the Germans. Like whatever they said, it wasn't true. What I remember most was like an announcement that the little children should go to the park, and they would have milk and food for the children. . so they took them, and they shipped them out, and the kids never came back. With this kind of lies, I always think twice

In the following significant statements Barbara described a feeling of trust

for her physicians, and yet, remaining somewhat fearful during office visits. "When I come to the doctor's office I feel very relaxed. I am very welcomed there, and I really shouldn't, but I still come there with palpitations."

When I go to a doctor's office, I really have palpitations. It really bothers me very, very much. I am a very sane person otherwise, I think, comparatively, but it is a phobia. I really don't like doctors. I have nothing against them personally, and some of them are my best friends.

Whenever I have a doctor's appointment I am not a happy camper. I am not thrilled about it, and I trust him, and I know he has my best health in mind. You know, as a matter of fact, I think that because of him I have stayed out of the hospital, because he doesn't rush to things. He is very conservative in this respect....I am very pleased with that. 
My ophthalmologist . . I was very, very pleased, and I trust him. He saved my eyes, because of the acute glaucoma. He had to put in an artificial drain. . . once faced with the necessity of that kind of treatment, I accept it, but I don't feel secure, I don't feel relaxed. I feel very upset about medical treatment.

The participants also described a connection to their physician. They needed the assurance that this was a person who could be trusted. Fred stated "When I came to the United States, it so happens that one of my first friends was a physician. This lady was originally from Vienna." Eve described "Many years ago I had a hysterectomy, about 30 years ago, so I hardly remember it. I had a good doctor. I had a doctor that was my aunt's friend, so I knew I was in good hands." She also described

When my husband died, I don't know how I survived it. . but I went to a doctor, who was a friend of my good friend's son. They graduated together. I asked him for some pills. I don't remember what I asked for, that somebody was using. . . so he opened a medical book. He said 'listen darling, you want to read it. Those are the side effects, do you want to get hooked on it, do you want to keep on taking it? Please don't. I suggest you don't take it.' I was, [shrugged her shoulders] you know, the way he told me, I think my headache went away because he was nice to me.

The following significant statements described the participant's reluctance to take medication. Eve described her skepticism "I take Lipitor regularly, more or less. My cholesterol was about 260 . I really didn't want to start taking something, but he said it was important." Doris described her hesitancy to start a new medication:

I am taking Fosomax, for three years. I have no problem with this in three years, but know, I went for a checkup, and the doctor said I should change, to take this hormones. . . and I have always, somehow, stayed away from it. At one time I had a fibroid on my breast. . . and I know, I am aware, that it is no good to take the hormones. I still had two to three weeks left, the Fosomax, so I decided I would finish, and then try the hormones, but I am so scared, with my breasts. 


\section{Formulated meanings}

The significant statements described the participants' trust of the doctor, fearful feelings while visiting the doctor, general mistrust, the special connections with the doctor, and reluctance to take medication.

\section{Theme cluster}

The formulated meanings were synthesized into the theme of Fear/Trust

\section{Dichotomy.}

\section{Exhaustive description}

The participants have described that they do go to the doctor, when the need is there, although they "have palpitations" and do not feel comfortable. They described that they trust their doctors, who in many cases came highly recommended by friends or family members. Some described the physician as a friend, or a friend of a family member, or a family member of a friend, which gave them the trust that they were in "good hands." Even though they had found a physician they trusted, the therapy that he prescribed was often feared (see Figure 1, p. 58).

\section{Theme 4 - Security}

This theme was titled Security because security is defined as "freedom from danger, risk ... anxiety or doubt," and "freedom from financial cares" (Flexner, 1989, p. 1731). It was the male participants primarily, who described concern for what might lie ahead with regard to their health care needs. They described that they wanted the assurance (synonym for security) that when they reach the point where they need health care, the funds for it would be there. They also wanted the assurance that when they reach a stage where they could no longer care for themselves, they would 
avoid institutionalization (described in Theme 1) by having sufficient funds for care at home.

During the Holocaust, the concentration camp inmates didn't have currency or possessions as security, although they had skills, wits, and talents that made them useful to the Nazis. It was perceived by the inmates that usefulness reduced their risk for death in the gas chambers.

\section{Significant statements}

In the following significant statements Barbara and Doris described their usefulness. Barbara stated, "They [the Nazis] found out that I spoke German and they needed someone for the switchboard." Doris described the special skill that made her useful to the Nazis.

I worked in an airplane factory during the war. . . I had to put screws in the wheels of the airplanes and I could go under and do it better than others could ... because I was an acrobat as a child.

The following significant statements described the participants' current concern for health insurance coverage. Doris stated, "I have private insurance and I had always, before."Aaron described something similar "I have had private insurance, and when I came of age I had Medicare plus supplemental insurance. . . We have home health insurance in case we need it in the future. Fred also described insurance coverage.

Nothing but the best. I find, let's face it, the health care has changed, since I came to the United States. I lived in Canada, there was a tremendous change in Canada. Canada became Medicare. Everyone that lives in Canada has free Medicare. . leaves a lot to be desired, basically though it is OK, I think. I have Medicare, I have private insurance, secondary insurance. I don't believe in HMO's.

In the following statement, George described his concern for other people who do not have health insurance. "I have Medicare insurance, but my heart goes out for those 
people who do not have insurance. There are 40 million children who are not insured."

He also stated "The only thing that I would say is that it amazes me that the United States is the only country, in the Western industrialized world, that doesn't have universal health care, which is not right."

Charles described his concern for other Holocaust survivors who are not insured.

I know survivors who are being helped by Jewish Family Services, because of the poverty they are experiencing, they like the help, they need the help, and they don't have the help. Some of them are very sick. They don't have insurance and they have big problems.

George, Charles, and Aaron described their concerns for the financial means to

receive care at home, for themselves and other survivors.

The worst thing that happened is that I had a very dear friend of mine, he died last May, he had Parkinson's. It was a tremendous, tremendous burden, although he was a rich man. He had to hire a private person, because he became incontinent and he couldn't feed himself, his wife died and he was by himself, his kids were living in New Jersey. He had to have a private man to take care of him. It was tremendously expensive. I see here people who suffer from Alzheimer's. It is a tremendous load on their spouses. They do not have the means to relieve the burden of the spouse, because if you have a live-in nurse, it is very expensive.

What we are trying to do is get the insurance for long term health coverage. The insurance money actually should be coming now from that money that is being negotiated [with European insurance companies for unclaimed policies]. Now what we essentially need is help in the house, have a nurse come in ... when somebody is totally unable to handle his or her own condition, the insurance coverage should provide for all that.

I read in the paper that there might be a settlement made to collect unpaid policies that our people had in Europe. I hope this money will help the survivors that are in need, that don't have money for home health. Most of us are in our seventies and eighties. I don't expect to live forever, but if you don't have financial help, it is hard to get by.

Formulated meanings

The participants' significant statements reflected concerns for insurance coverage 
for health care and the financial means to receive care in their homes.

\section{Theme cluster}

The formulated meanings were synthesized into the theme of Security.

\section{Exhaustive description}

Barbara and Doris, who gave examples of their usefulness to the Nazis, described security, during their imprisonment in the concentration camps. They believed that usefulness was a pivotal issue in the selection process for the gas chambers.

The male participants of this study described the majority of the significant statements related to the theme of security. They described the need for health insurance coverage, which gave them the assurance that when the need arose for health care, the funds for it would be there. Several described concerns for other people who did not have adequate health insurance coverage. Some expressed concerns for home health insurance coverage. They expressed their need for the financial means to have help at home when they reach a time when they cannot care for themselves. They spoke about the burden on family members when someone becomes unable to care for him or herself. A few described their hope that a settlement made with European insurance companies might help provide home health insurance coverage to help relieve this burden, while allowing the aged person to remain at home. The participants seemed to describe the security that financial means, insurance coverage, and remaining in their own home would provide for the aging Holocaust survivor (see Figure 1, p. 59).

Theme 5-Luck

Luck was a term that arose repeatedly in the participant's descriptions of how they survived the Holocaust. Even though, as concentration camp prisoners, they tried to 
appear able bodied and hard working, it was often the randomness of the selection process that caused many to die in the gas chambers. Descriptions of miracles and good fortune were included in this theme because they described situations which were beyond their control. The participants described that it was a "miracle" that they survived, or they were "lucky." They felt that it was this same "luck" that brought them relatively good health.

\section{Significant statements}

Barbara described two situations in which "miracles" saved her life in the Concentration camp.

I was supposed to sew buttons, and I never sewed a button in my life. I never finished my quota, and I thought they [the Nazis] would punish me for sure, but thankfully enough they found out I spoke German, and they needed somebody for the switchboard, and this is what throughout, I always call my little miracles. One miracle after another, that I survived, plus the will to live.

One day we had to walk eight kilometers to the factory, through the snow. This time we did not even have shoes anymore, because in Auschwitz we never removed our shoes, because they were always wet. If you removed the shoes at night, the feet swelled up so in the morning, you couldn't put them on again, so we just slept in the shoes until they fell apart. Then we only had wooden shoes, wooden pieces strapped to our ankles. To walk through the snow, for eight kilometers, it was horrible, and my malaria, with the fever up and fever down. . so I came to the infirmary, and I stood in line, and I fainted. There were two Hungarian girls who recognized me. I was once able to save them from a beating in Auschwitz. They carried me into the infirmary, and the doctor in the infirmary was a friend or a relative of theirs. When they told her what I did for them, in Auschwitz, she registered me as a nurse, as a helper in this infirmary, so I didn't have to walk to the factory again. This saved my life at the time, again a miracle.

In the following significant statements Barbara described that luck was

responsible for her survival in the concentration camps.

It just so happens my whole group was transferred to another part of the camp [Auschwitz], because my number was never taken down in the infirmary. I was very, very lucky in this respect. . . This nail had to be removed. . . it was full of 
pus. Two men had to hold me because [in the camps] we had no anesthesia, but I was lucky that I was being treated, because at the time, they needed me.

... then they took us all to concentration camps, because we were political prisoners. I was eight months there. . . and I was lucky that I was a good worker and healthy. I guess I was healthier than other girls who didn't make it.

The cut was on my cheek. . they had to drain that because there was so much pus. You cut a little bit off center and you can paralyze the whole face. . . . . so I was very, very, very fortunate, and once the swelling started coming down, it settled right here, and it doesn't show.

The participants described that luck again, was responsible for their relatively good health today. Eve stated, "I can go to a doctor for checkups, but I try not to, luckily, I guess I don't need." George's description was similar, "I have been very, very lucky. I have not had too many experiences, I don't have any special difficulties in this area, because I am relatively healthy."

\section{Formulated meanings}

The significant statements described "miracles" and "luck" that they survived the concentration camps and "luck" that they are healthy today.

\section{Theme cluster}

The formulated meanings were synthesized into the theme of Luck.

\section{Exhaustive description}

The participants felt that their survival, during the Holocaust, was the result of luck and miracles. Presently, they described their need for health care as minimal, compared to so many in their age group. They felt that this also, was a matter of luck (see Figure 1, p. 59).

The following poem by Bertolt Brecht, author and Holocaust survivor, described luck and survivor guilt for, perhaps, creating his own luck. 
$\underline{\mathrm{I}}$, the survivor

I know of course; it's simply luck

That I've survived so many friends. But last night in a dream

I heard those friends say of me: 'Survival of the fittest'

And I hated myself (Schiff, 1995, p.127).

\section{Theme 6 - Need for Understanding}

The participants described their need for understanding of the uniqueness, scars, vulnerability, and survivor guilt that resulted from their Holocaust experience.

\section{Significant statements}

The participants described the uniqueness, scars and vulnerability of Holocaust survivors. Charles described that "It is very important that the people in the profession get to know the extent of the hurt that happened to those people ... why it is a unique situation for the medical profession to alleviate." Charles also described the following:

How the nurse can help a survivor in a hospital situation is a very interesting question. ... Although nurses do have the ability to care for patients, not many would have the ability or knowledge to handle such cases. Those are unique cases, although in medical terms they will not be different from what a nurse will encounter everyday, on the floor or in a nursing home.

Cases like these are unique simply because the people have somehow managed to go through fifty years of life after (the Holocaust), without even thinking that someday this experience will come to be a burden on their later life. Now what I'm saying is there was a period of over fifty years where we did not think of ourselves as any different than the next person, but now we see the degree to which, when things happen physically, emotionally, it just comes up much stronger in many ways.

Dealing with patients, you can immediately recognize someone different from the average patient. It is not distrust, it is just that feeling that a survivor gets brought back to, it immediately brings a person back to his suffering during the Holocaust.

Eve, Doris, and Fred described scars and vulnerability:

Well it helps, a nurse, if they would show sometimes some kindness because a person who went through hell, like I, you see, I can cry in a second, and in other ways I am pretty normally functioning. There are scars, and you know, there is a 
period that is very difficult when you get older. When you are younger, I think it is easier, but when you are older, you sort of live on the past. I think a nurse needs a little understanding, or feeling, for an older person.

I think we are a little more sensitive. For so many years we were told what to do, and we had to follow it. . so if somebody doesn't speak nicely to us, it makes me think that maybe he tricks me, like in the camp. . . with taking the blood. I understand they were making experiments.

I don't think that there are many, if any, survivors who don't have psychiatric or emotional scars. My wife tells me that sometimes, at night, I yell out or cry. I don't remember, but this is what my wife tells me. I wake up sometimes, covered in sweat, and I don't know why. Emotionally, I think we are all impacted, every one of us, but life goes on.

In the following significant statements Aaron and Charles described other

Holocaust survivors reliving the concentration camp experience.

I have never been in the hospital, but my wife has. When she was there one evening she suddenly thought she was back in the camps. She became hysterical, and the nurses had a tough time trying to calm her down.

I have spent some time with a cousin of mine in New York. She was hospitalized and then put into a nursing home, and I can write a book just about the way she acted. She is a survivor. She's about eighty some. She saw all kinds of things on the ceiling. When I brought her home, I had made arrangements with the local [home health] service, through her insurance, she had private insurance, tied in with Medicare. They had to send five different people before she agreed to have one stay, to help her. She would think up all kinds of goblins about a male nurse, who would come in every three days to check her vital signs. The women, who came in to help her, she couldn't stand. She found all kinds of excuses to get rid of them, everything was connected to the Nazis.

The following statement is Fred's description of survivor guilt.

I said to my wife, I think that every survivor, or $99 \%$, has emotional problems. It wouldn't be human not to have them. One of the things, for example, that I remember with such sadness, and it gives me sleepless nights, is the liberation. Usually people think of the liberation as what you see in movies, the prisoners of war are dancing. We were liberated and what you saw, a few men sitting and crying. Why are we alive? Why not the others? I know most of us have such a feeling of guilt. It is emotional! 
Eve described two situations where there was a lack of understanding on the part of her physicians.

I think a lot is left unsaid by the doctors . . a an HMO doctor doesn't give you much direction, or time, you know. It is like I ask a question and he is already out the door. If I say I don't sleep, he just shrugs his shoulders.

I took tests, and they called me, but the doctor didn't get on the phone to talk to me directly . . just left a message on the machine that everything is OK. It would be nice if there was a human communication.

Doris spoke very clearly about the need for understanding. "A nurse needs to be a little kinder and understanding."

\section{Formulated meanings}

The significant statements of the participants described the uniqueness of their experience, their scars, their vulnerability, and survivor guilt. They described their desire for understanding of these things by nurses and physicians.

\section{Theme cluster}

The formulated meanings were synthesized into the theme of Need for

\section{Understanding.}

\section{Exhaustive description}

The participants described the uniqueness of their past and the scars that remained from their past experiences with the Nazis. Some described situations where being in a hospital and nursing home had caused their family members to relive the concentration camp experience all over again. One survivor spoke for many as she related that as younger survivors, it was easier to stay in the present, but now, as older people, they are taken back to the past more readily. Many described the way their past experiences impact upon their need for kindness and understanding. The participants described their 
desire for understanding from nurses and other health care providers (see Figure 1, p. 59). Essence of the Jewish Holocaust survivor's health care experience

The six themes which emerged through the data analysis process were Hiding and Avoiding, Self Care, Fear/Trust Dichotomy, Security, Luck, and the Need for Understanding. Hiding and Avoiding described the participants' continuing with self protective behaviors learned from their Holocaust experience. They described self care activities which enabled them to continue to avoid the health care system. Fear/Trust Dichotomy described behaviors which were again in self protection mode. Security was provided through the purchase of health insurance policies, which assured them that when the need for health care was unavoidable, the necessary funds would be available. The first four themes described self protection and self preservation behaviors in which the survivors were actively engaged. The participants were adamant that those behaviors would be of no avail without the element of luck. They also expressed that when the time arrives when they can no longer avoid the health care system, they need to be treated with understanding of their past experiences. The totality of their self protective behaviors, the element of luck, and understanding from health care professionals has led to continued survival for the aging Holocaust survivor. The essence of the Jewish Holocaust survivor's health care experience in the United States today is that protection is necessary for their survival (see Figure 1, p. 58-59).

Summary

The transcriptions from seven interviews were studied. Sixty two significant statements were extracted and analyzed for meaning. The formulated meanings were synthesized into the six themes: Hiding and Avoiding, Self Care, Fear/Trust Dichotomy, 
Security, Luck, and Need for Understanding. The essence of their experience was derived from these six themes. During the validation step of the process the participants agreed that survival was the essence of the descriptions of their experience. This concluded the data analysis process. 
Figure 1

Data Analysis Using Colaizzi's Method

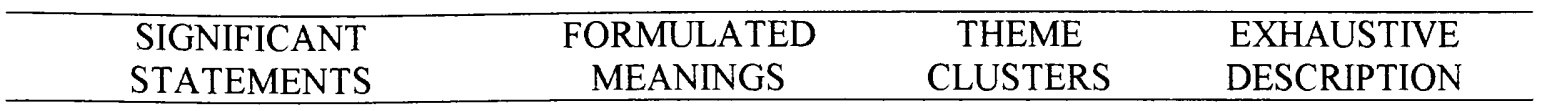

A tiny sore and you were sent to the gas chamber.

Doctors. . I avoid them like the plague.

HRT is probably important but 1 don't do it.

Survivors. . . don't like to end up in a nursing home.

We packed the wound with snow to stop the bleeding.

I exercise. I have skim milk, tofu, and green salads.

They were telling lies...I always think twice.

A doctor's appointment... I'm not a happy camper. Because of him I stayed out of the hospital.

I went to a doctor who was a friend of my friend's son.

Lipitor... I really didn't want to start taking something.

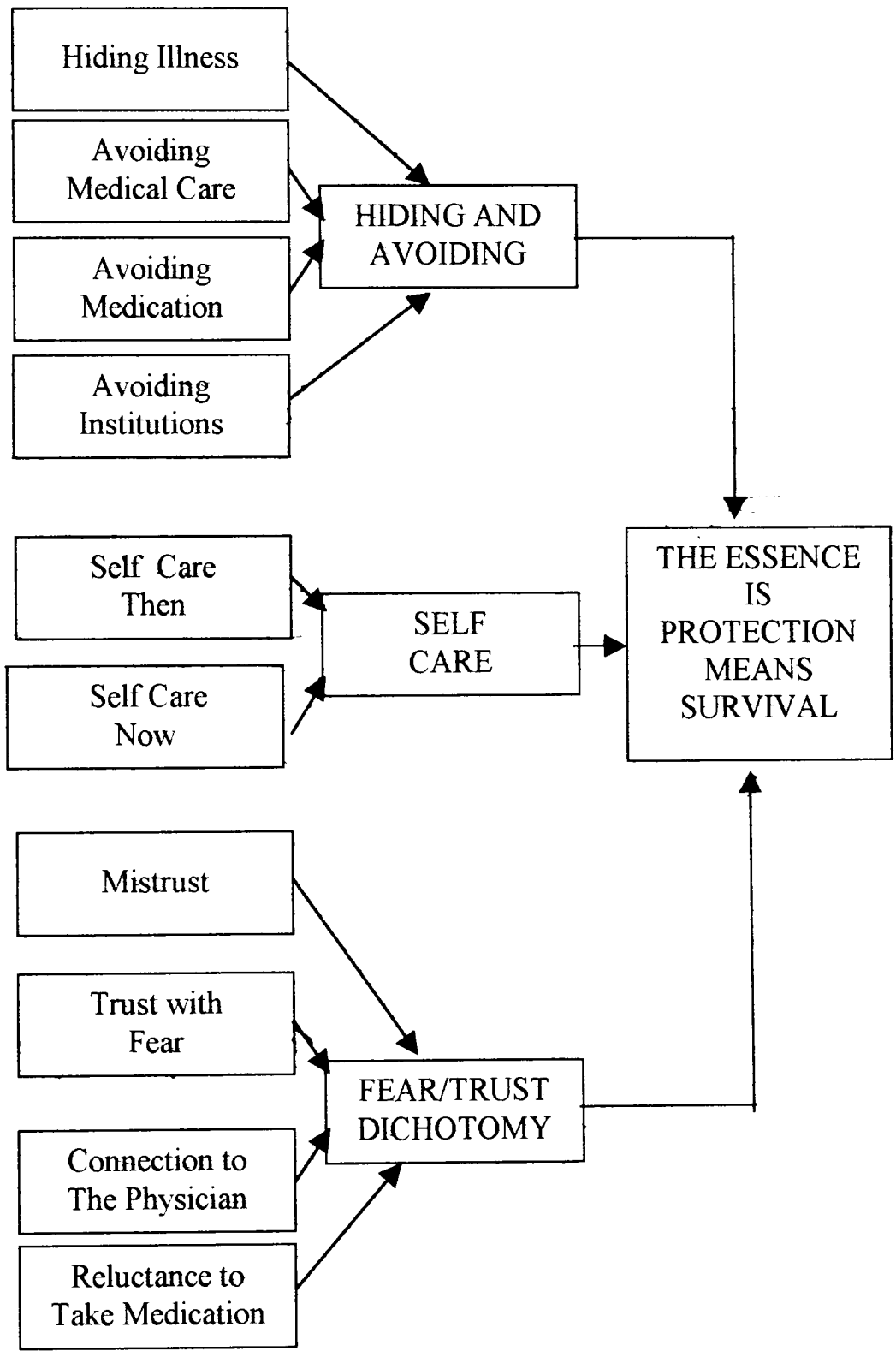


Figure 1 (continued)

Data Analysis Using Colaizzi's Method

\begin{tabular}{cccc}
\hline SIGNIFICANT & FORMULATED & THEME & EXHAUSTIVE \\
STATEMENTS & MEANINGS & CLUSTERS & DESCRIPTION \\
\hline
\end{tabular}

They found out I spoke German...

They don't have insurance and they have big problems.

It was a tremendous burden. .. he had to hire a private person.

One miracle after another, that I survived.

My whole group was transferred. . I was very, very lucky.

I have been very, very lucky. .. I am relatively healthy.

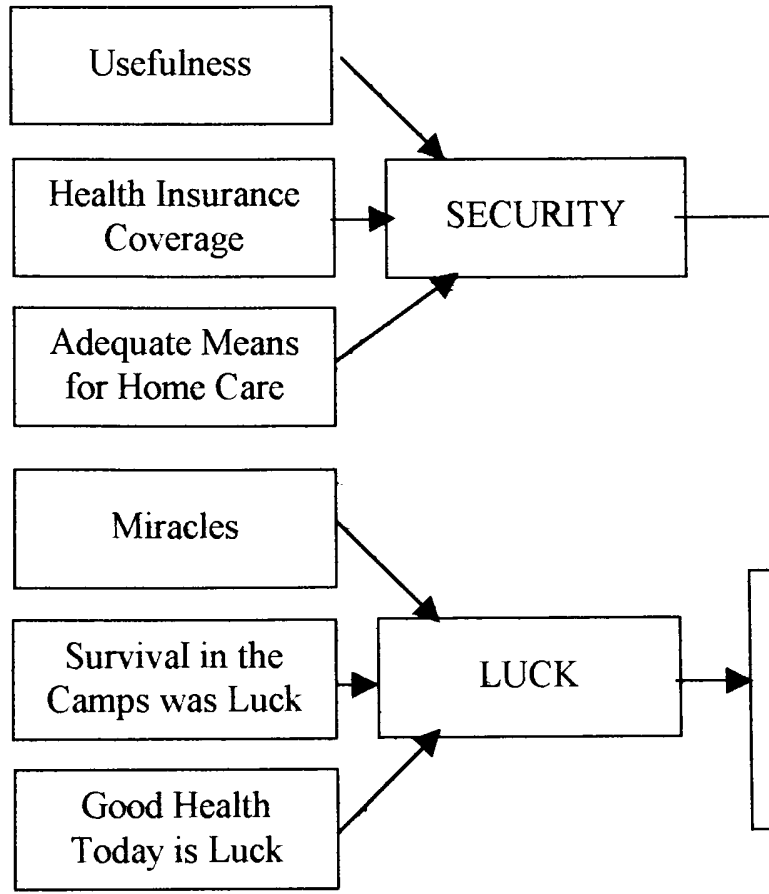

THE ESSENCE IS PROTECTION MEANS SURVIVAL

You can imediately recognize someone different from the average patient.

It is important to know the extent of the hurt that happened.

When things happen physically, emotionally, it just comes up stronger.

In the hospital, she suddenly thought she was back in the camps.

If I say I don't sleep, he just shrugs his shoulders.

A nurse needs to be a little kinder and understanding.

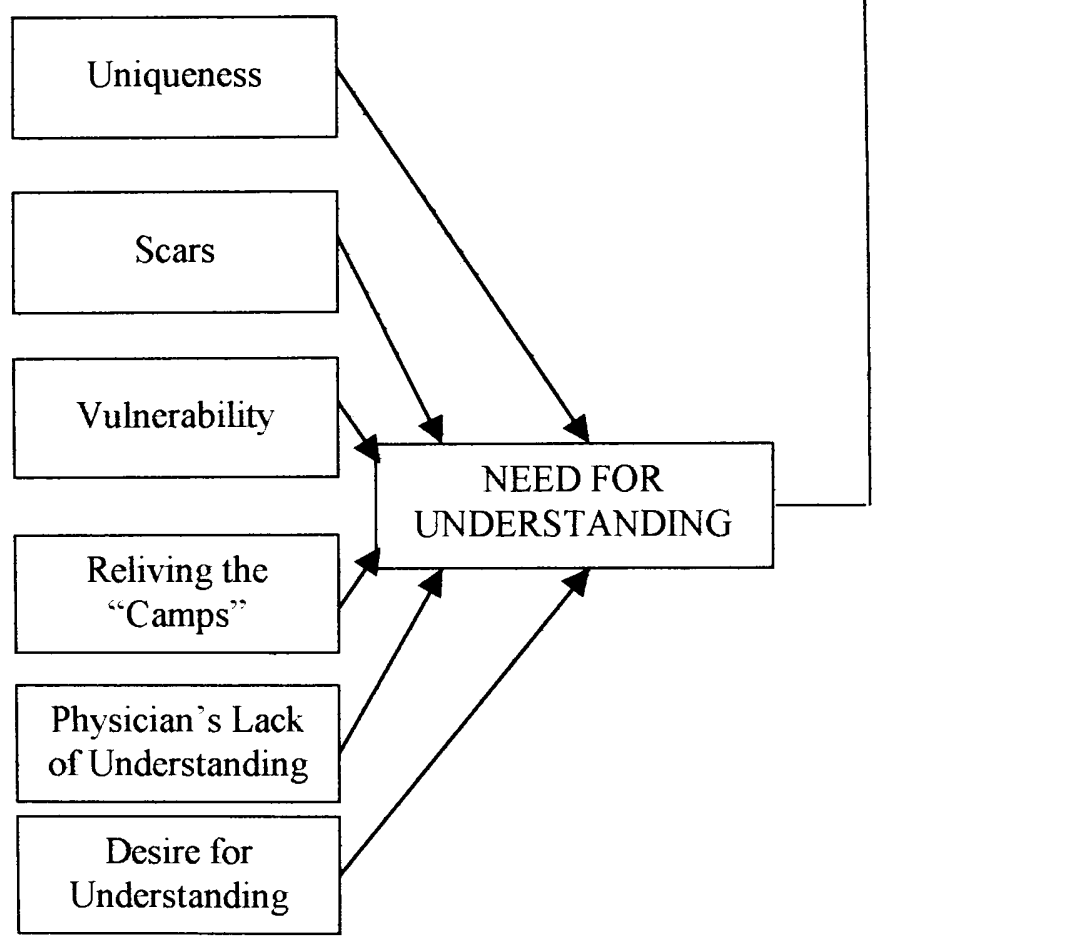




\section{Chapter 5}

\section{Conclusions}

This chapter includes a discussion of the research findings, and conclusions drawn from the findings. This chapter also includes the limitations of the study and recommendations for further research on the phenomenon of interest. Most importantly, included in this chapter, are the implications for nursing practice related to the findings of this study.

\section{Discussion}

The participants of this study spoke of health care experiences that were unique to the Jewish Holocaust survivor. As the researcher described in chapter one, interest in this phenomenon was generated by a personal experience, in the hospital, with an elderly Jewish Holocaust survivor. In that case a simple finger stick for blood glucose triggered a response of terror from the patient. The researcher was interested in learning, from the survivors, what their experience was with health care in the United States today. Analysis of the data from seven interviews revealed health care behaviors and needs which were organized into six themes.

Theme one, Hiding and Avoiding, described the survivor's attempts to hide illness, thus avoiding the health care system, as much as possible, particularly hospitals and institutions. As Charles stated, "survivors, as a whole do not like to wind up in a nursing home." According to Adams et al. (1994), "institutionalization represents loss, change of status, separation, and possibly abandonment which all recall their earlier trauma and produce a sense of loss of personal control" (p. 101). 
In theme two, Self Care, the female participants described self care activities, then and now. They described, "pinching their cheeks" and "stuffing their clothes" to make themselves look healthier in the concentration camps. They believed that those self care activities helped them avoid selection for the gas chamber. The participants described self care activities today, such as exercising, relaxation techniques and eating "healthy" foods. These self care activities were perceived as helping them avoid the health care system today. Self care activities also allowed them to maintain a sense of personal control. For several years now Holocaust survivors have been taping accounts of their Holocaust experience. This is a form of self care for their mental health. Krell (1985b) began taping projects in Canada in 1980. Most of the survivors who participated in that program related that speaking about their experiences gave them a sense of personal well being and a sense of closure.

Theme three, Fear/Trust Dichotomy, described the survivor using the health care system when necessary. Trust was described as an important issue in the selection of a physician. For example, Doris stated "I went to a doctor who was a friend of my good friend's son. They graduated together." Most of the participants described their need for a connection with the doctor, which provided a sense of trust. This sense of trust was tempered however, by the fear of new therapy, such as medication change. No articles were found in the review of the literature that related to Fear/Trust Dichotomy.

Security, theme four, was described primarily by the male participants of the study. The significant statements spoke of the importance of health insurance coverage and the financial means to provide for care in their own homes. This was another way the 
Holocaust survivor avoided institutionalization. No articles were cited in the literature review that referred to security.

Theme five was Luck. All of the participants agreed that their survival, during the Holocaust, was a matter of luck. These findings were similar to those of Bower (1994), who conducted a phenomenological study of the long-term psychiatric and sociological consequences of the "death" experience. During interviews with 186 Holocaust survivors, the majority of the subjects "stated spontaneously that ultimately their survival was beyond their control and a matter of luck" (p. 392). George described his health care experience, "I have been very, very lucky. I don't have any problems in this area, because I am relatively healthy." The other participants also felt that their "good health" status was a matter of luck.

Theme six described the Jewish survivor's need for understanding of their Holocaust experience. Doris stated this very succinctly, "A nurse needs to be a little kinder and understanding." Eve described her physician's lack of understanding of her difficulty sleeping. "If I say I don't sleep, he just shrugs his shoulders.” Rosen, Reynolds, Yeager, Houck, and Horowitz (1991) studied sleep disturbances in Holocaust survivors. Their findings revealed significantly greater sleep disturbances in the Holocaust survivor group than in their other subjects.

Fred described "sleepless nights" in association with survivor guilt. "Why are we alive? Why not the others?" Garwood (1996) described the four elements of survivor guilt as being powerlessness, annihilation anxiety, object loss, and torture. According to Garwood, "all four reinforce each other but powerlessness in the face of annihilation threat is of greatest importance" (p. 245). The author described that powerlessness in later 
life, as the survivor became ill or aged, evoked unconscious memories of the earlier vulnerable state. Hantman, Solomon and Prager (1994) studied 192 Holocaust survivors living in Israel during the Gulf War in 1991. The findings of that study revealed that those who had experienced more severe trauma during the Holocaust demonstrated the highest level of vulnerability in the presence of another life stressing event. The participants of this study spoke about their scars, their uniqueness, and their sensitivity. Their previous trauma, from the Holocaust, has not had an inoculating effect towards stressful life events, especially illness. It has made them feel more powerless and more vulnerable.

In conclusion, themes one through four, Hiding and Avoiding, Self Care, Fear/Trust Dichotomy, and Security all described self protection and self preservation behaviors and needs. Theme five, described the belief that good health was a matter of luck. Theme six expressed the Holocaust survivor's need for understanding. Together the six themes described self protection and self preservation behaviors and needs which led to continued survival for the participants of this study. This was the essence of the Jewish Holocaust survivor's health care experience in the United States today. The essence may be visualized using the conceptual model (see Figure 2, p. 64). The nurse and other health care providers must understand the Holocaust survivor within the context of their experiences, as described in this study. Knowledge of those experiences may direct the nurse in implementing creative and appropriate nursing interventions to provide comfort and assist the Holocaust survivor with their health care needs. 


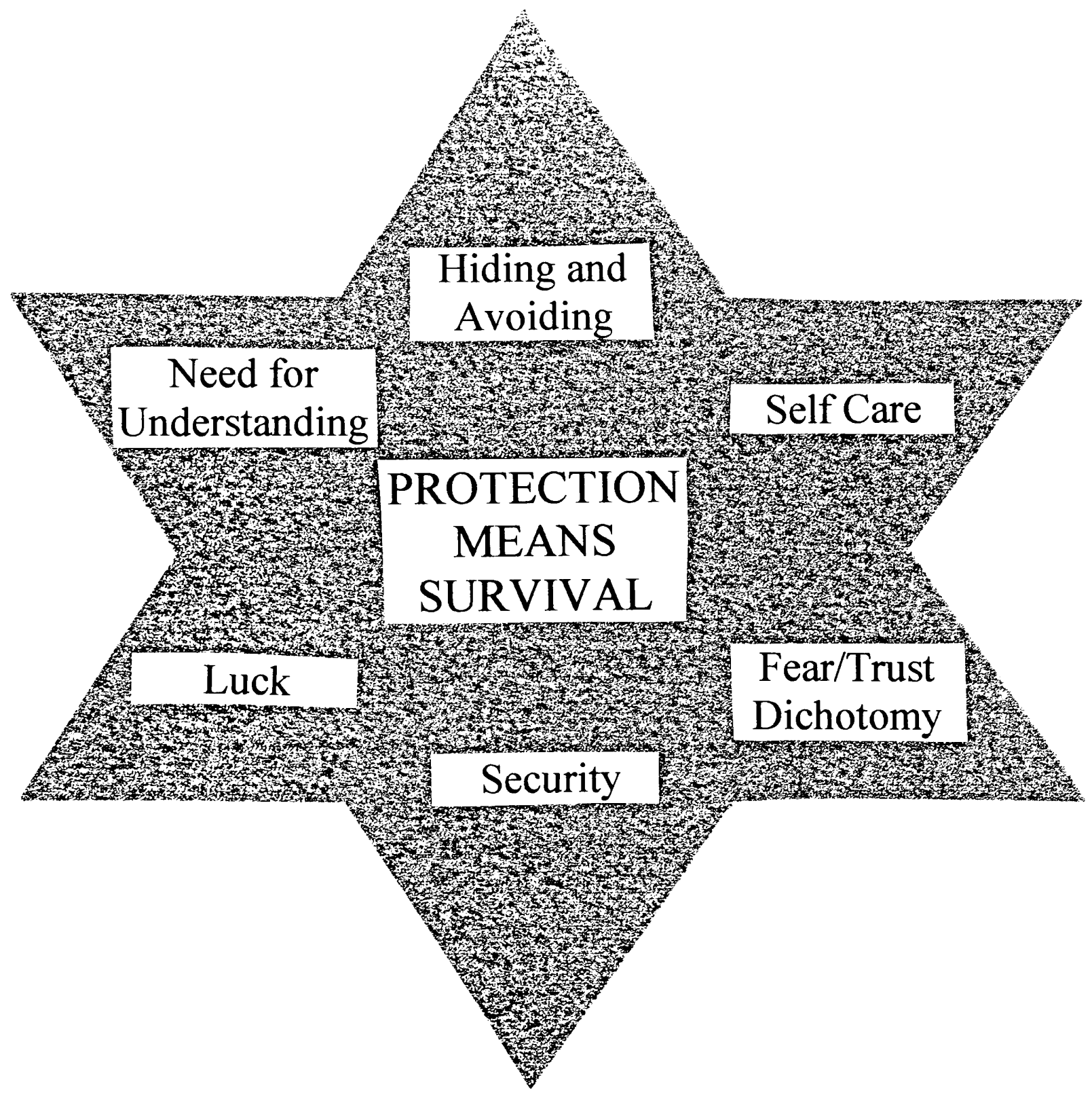

Figure 2. This is a conceptual model of the essence of the Jewish Holocaust survivor's experience with health care in the United States today 


\section{Limitations of the Study}

This study was limited to a convenience sample of survivors referred to the researcher by the Holocaust Documentation Center at Florida International University. The seven participants were Jewish Holocaust survivors known for speaking about their experiences. The results of the study may not reflect the needs and behaviors of Holocaust survivors who are unwilling to speak about their experiences.

Additionally this study was limited geographically to South Florida. The findings may not represent Holocaust survivor's health care experiences in other parts of the United States.

This study was limited by the exclusion of Holocaust survivors with known psychiatric disorders. This study was also limited by the exclusion of Holocaust survivors with known unstable medical conditions. The findings of this study may not reflect the health care experiences of those portions of the Holocaust survivor population.

\section{Recommendations for Further Research}

Some of the significant statements from the participants were divided along gender lines. Self care activities were described by the female participants only. Primarily the male participants described the importance of health care insurance coverage. A comparative study might be useful in differentiating between the needs of male and female Jewish Holocaust survivors.

The study was limited geographically to South Florida. Replication of the phenomenological study in other parts of the United States, or World, would be worthwhile to determine if Holocaust survivors' health care experiences or needs are similar. 
The study was limited by the exclusion of survivors with known psychiatric disturbances and unstable medical conditions. Further phenomenological exploration should be done to include those portions of the Jewish Holocaust survivor population. The development of nursing interventions to accommodate their unique needs seems necessary.

Implications for Nursing

One of the interview questions was "how can the nurse assist in meeting the Holocaust survivor's health care needs." The participants of this study were very clear in their descriptions of their need for understanding of their uniqueness and scars from their Holocaust experiences. The nurse must be alert to signs that these clients are Holocaust survivors, aside from the numbers that may be tattooed on their arms. According to Williams (1993), sometimes during the course of an assessment the Holocaust survivor may give clues to their past experience. It is important that the nurse allow time for the survivor to describe their experience. If the survivor seems reticent to speak about the experience, their silence must be respected. Bader, Peretz, and Kaplan De-Nour (1993), noted that some survivors suppress their past experience as a coping mechanism.

A notation should be placed on the patient's care plan that he or she is a Holocaust survivor, including any special needs that might have been indicated. The researcher feels that in the case of the patient who was upset by the accucheck (discussed in chapter 1), knowing that this patient was a Holocaust survivor would have changed the nursing intervention. In the future, a student would perform a skill on a Holocaust survivor/patient, only if they were caring for the patient for the entire shift, and after a relationship with the patient had been established. 
Nurse administrators, who provide orientations and continuing education for their employees, should consider including a guest speaker who is a Holocaust survivor. The sensitivity toward the survivor's uniqueness must begin with administration, who set the tone for the care given in their acute and long term care facilities. The participants of this study stated that Holocaust survivors prefer to avoid 'institutionalization' in a nursing home. There may be cases where a nursing home is the only option for survivors who can no longer care for themselves. Charles spoke about his cousin, who was a Holocaust survivor in her eighties. When the elderly woman was in a nursing home temporarily, after a hospitalization, she seemed to relive the concentration camp experience. Charles stated that his cousin, who never had hallucinations before, "saw all kinds of things on the ceiling."According to Adams et al. (1994), a Holocaust survivor entering a nursing home should be given choices, and allowed to be part of the planning process for their care. This gave the participants of their study a sense of well being and personal control.

Nurse practitioners need to be cognizant of the fact that survivors may attempt to hide illness, be reluctant to ask questions, and prefer to avoid visits to the primary care provider. The participants described that when new medications were prescribed, they were hesitant about trying them. Perhaps allowing the Holocaust survivor time to express his or her concerns about the new medication could enhance compliance with the medication regime. The extra time spent would add to the feeling of trust, which was described as being important to them.

Nursing education has advanced to include courses on cultural diversity in nursing care. It is important for nursing educators to recognize that the Jewish Holocaust survivor's experience is not synonymous with the experience of Jewish clients who are 
not Holocaust survivors. A section on Jewish Holocaust survivors should be included in the nursing curriculum, particularly in parts of the country, or world, where there is a concentration of Jewish Holocaust survivors.

While in the process of seeking participants for this study, the researcher was informed about a Holocaust survivor who had required neurosurgery. In preparation for the surgery, shaving of his head precipitated a psychotic episode. Emotionally, he was taken back to "the camps," where routinely the prisoner's heads were shaved upon arrival. Reports were that this previously highly functioning survivor, never recovered from this episode. The researcher must ask the question, could this new trauma have been prevented through a better understanding of the Holocaust survivor's experience?

\section{$\underline{\text { Summary }}$}

The diversity of the nursing profession places nurses in many different settings and roles. As case managers, acute care nurses, nurse administrators, perioperative nurses, mental health nurses, nurse educators, and nurse practitioners, etc., the opportunity to provide care for the aging Jewish Holocaust survivor may arise. The participants of this study have described their health care behaviors and needs. They described how their past experiences impact upon their need for understanding. The researcher interpreted these behaviors and needs as being forms of protection, which have led to their continued survival. This was described as the essence of their health care experience. In order to fulfill the role of client advocate, nursing must accept the responsibility for protecting the Holocaust survivor/patient. They must be treated with the understanding that protection means survival to the aging Jewish Holocaust survivor. 


\section{References}

Abromowitz, M. Z., Lichtenberg, P., Marcus, E.L., \& Shapira, B. (1994). Treating a survivor without addressing the Holocaust: A case report. Clinical Gerontologist, 14 (3), $75-80$

Adams, K.B., Mann, E. S., Prigal, R.W., Fein, A., Souders, T.L., \& Gerber, B.S. (1994). Holocaust survivors in a Jewish nursing home: Building trust and enhancing personal control. Clinical Gerontologist, 14 (3), 99-117.

Baider, L., Peretz, T., \& KaplanDe-Nour,A. (1992). Effect of the Holocaust on coping with cancer. Social Science Medicine,34 (1), 11-15.

Baider, L., Peretz, T., \& Kaplan De-Nour, A. (1993). Holocaust cancer patients: A comparative study. Psychiatry, 56 (11), 349-354.

Bar-Tur, L. \& Levy-Shiff, R. (1994). Holocaust review and beating witness as a coping mechanism of an elderly Holocaust survivor. Clinical Gerontologist, 14 (3), $5-15$.

Bower, H. (1994). The concentration camp syndrome. Australian and New Zealand Journal of Psychiatry, 28, 391-397.

Chodoff, P. (1981). Survivors of the Nazi Holocaust. Child Today. 2-5.

Colaizzi, P. F. (1978). Psychological research as the phenomenologist views it. In R. Valle \& M. King (Eds.), Existential phenomenological alternative for psychology (pp. 48-71). New York: Oxford University Press.

Danieli, Y. (1988). Confronting the unimaginable: Psychotherapists reaction to victims of the Nazi Holocaust. In Wilson, J.P., Harel, Z.,\& Kahana, B.(Eds.). Human adaptation to extreme stress: From the Holocaust to Vietnam. New York: Plenum. pp 219-238.

Dasberg, H. (1987). Society facing trauma or psychotherapist facing survivors. Israel Journal of Psychotherapy, 1, 98-103.

Eitinger, L. (1992). Identification, treatment, and care of the aging Holocaust survivor. The first national conference on identification, treatment, and care of the aging Holocaust survivor (pp. 5-15). Miami; Florida International University.

Fenig, S. \& Levav, I. (1991). Demoralization and social supports among Holocaust survivors. The Journal of Nervous and Mental Disease, 179, (3), 167-171. 
First, M. (Ed.) (1994). DSM-IV (4th ed.). Washington, DC: American Psychiatric Association.

Flexner, S.B. (Ed.) (1989). The Random House dictionary of the English language (2nd ed.). New York : Random House.

Frankl, V. E. (1963). Man's search for meaning. New York: Simon \& Schuster.

Garwood, A. (1996). The Holocaust and the power of powerlessness: Survivor guilt an unhealed wound. British Journal of Psychotherapy, 13 (2), 243-258.

Giberovitch, M. (1992 a). Decisions, issues, and innovative responses concerning families of survivors. The first national conference on identification, treatment, and care of the aging Holocaust survivor. (Pp. 64-74). Miami: Florida International University.

Giberovitch, M. (1992 b). Establishing trusting relationships with clients. The first national conference on identification, treatment and care of the aging Holocaust survivor. (pp. 42-57). Miami: Florida International University.

Hantman, S., Solomon, Z., \& Prager, E. (1994). How the Gulf War effected aged Holocaust survivors. Clinical Gerontologist, 14 (3), 27-37.

Kahana, E., Kahana, B., Harel, Z., 7 Rosner, T. (1988). Coping with extreme trauma. In Wilson, J.P., Harel, Z., \& Kahana, B. (Eds.). Human adaptation to extreme stress: From the Holocaust to Vietnam. New York: Plenum. (pp. 65-79).

Kaminer, H. \& Lavie, P. (1991). Sleep and dreaming in Holocaust survivors: Dramatic decrease in dream recall in well-adjusted survivors. The Journal of Nervous and Mental Disease, 179 (11), 664-669.

Kaplan, H. \& Sadock, B. (Eds.) (1998). Synopsis of Psychiatry (8th ed.). Baltimore: Williams \& Wilkins.

Krell, R. (1985 a). Child survivors of the Holocaust: 40 years later. Journal of the American Academy of Child Psychiatry, 24 (4), 378-380.

Krell, R. (1985 b). Therapeutic value of documenting child survivors. Journal of the American Academy of Child Psychiatry, 24 (4), 397-400.

Krell, R. (1992). Aging Holocaust survivors: Memory, nostalgia, \& treatment issues. The first national conference on identification, treatment, and care of the aging Holocaust survivor. (pp. 22-31). Miami: Florida International University.

Krell, R. (1993). Child survivors of the Holocaust - Strategies of adaptation. Canadian Journal of Psychiatry, 38 (8), 384-389. 
Lange, A. (1996). Using writing assignments with families managing legacies of extreme trauma. Journal of Family Therapy, 18 , 375-388.

Lee, B.S. (1988). Holocaust survivors and their internal strengths. Journal of Humanistic Psychology, 28 (1), 67-95.

Leininger, M. M. (Ed.). (1985). Qualitative research methods in nursing. Orlando, FL: Grune \& Stratton.

Lichtenberg, P. \& Marcus, E. (1994). Paranoid psychosis in a Holocaust survivor. Clinical Gerontologist, 14 (3), 41-46.

Magids, D.M. (1998). Personality comparison between children of hidden Holocaust survivors and American Jewish parents. The Journal of Psychology, 132 (3), 245-254.

Major, E.F. (1996). The impact of the Holocaust on the second generation Norwegian Jewish Holocaust survivors and their children. Journal of Traumatic Stress, 9 (3), 441-453.

Mish, F.C. (Ed.) (1998) Merriam-Webster's Collegiate Dictionary (10th ed.). Springfield, Mass: Merriam-Webster.

Modai, I. (1994). Forgetting childhood: A defense mechanism against psychosis in a Holocaust survivor. Clinical Gerontologist, 14 (3), 67-71.

Peretz, T., Baider, L., Ever-Hadini, P. \& KaplanDe-Nour, A. (1994).

Psychological distress in female cancer patients with Holocaust experience. General Hospital Psychiatry, 16, 413-417.

Robinson,S., Rapaport-Bar-Sever, M. \& Rapaport, J. (1994). The present state of people who survived the Holocaust as children. Acta Psychiatrica Scandanavia, 89, 242245.

Rosen, J., Reynolds, C.F., Yeager, A.L., Huock, P.R., and Hurwitz, L.F. (1991). Sleep disturbances in survivors of the Nazi Holocaust. American Journal of Psychiatry, $148(1), 62-66$.

Rotenberg, L. (1985). A child survivor/psychiatrist's personal adaptation. Journal of the American Academy of Child Psychiatry, 24 (4), 385-389.

Safford, F. (1995). Aging stressors for Holocaust survivors and their families. Journal of Gerontological Social Work, 24, 131-153. 
Salamon, M. J. (1994). Denial and acceptance: Coping and defense mechanisms. Clinical Gerontologist, 14 (3), 17-25.

Schiff, H. (1995). Holocaust poetry. New York: St. Martin's Press

Schwartz, B.L. (1988). Holocaust survivors and internal strengths. Journal of Humanistic Psychology, 28 (1), 67-96.

Schwartz, E.A. (1995). Jewish Americans. In Giger, J.N. \& Davidhizar (Eds.). Transcultural nursing: Assessment and intervention. (2nd ed.). St. Louis: Mosby.

Schwartz, S., Dohrenwend, B.P., \& Levav, I. (1994). Nongenetic familial transmission of psychiatric disorders? Evidence from children of Holocaust survivors. Journal of Health and Social Behavior, 35 (12), 385-402.

Solomon, Z. (1995). From denial to recognition: Attitudes toward Holocaust survivors from WWII to the present. Journal of Traumatic Stress, 8 (2), 215-228.

Solomon, Z. (1996). Responses of mental health professionals to man-made trauma: The Israeli experience. Social Science Medicine, 43 (5), 769-774.

Solomon, Z. \& Prager, E. (1992). Elderly Israeli Holocaust survivors during the Persian Gulf War: A study of psychological distress. American Journal of Psychiatry, $\underline{149}, 1707-1710$.

Somor, E. (1994). Hypnotherapy and regulated uncovering in the treatment of older survivors of Nazi persecution. Clinical Gerontologist, 14 (3), 47-63.

Sorscher, N. \& Cohen, L.J. (1997). Trauma in children of Holocaust survivors: Transgenerational effects. American Journal of Orthopsychiatry, 67 (3), 493-499.

Steinitz, L. (1992). A half-century later: Aging Holocaust survivors and their families. The first national conference on identification, treatment, and care of the aging Holocaust survivor. (pp. 75-94). Miami: Florida International University.

Stermer, E., Bar-Tur, H., \& Levy, N. (1991). Chronic functional gastrointestinal symptoms in Holocaust survivors. The American Journal of Gastroenterology, 86 (4), 417-422.

Streubert, H.J. \& Carpenter, D.R. (1995). Qualitative research in nursing: Advancing the humanistic imperative. Philadelphia: Lippincott.

Tauber, Y. \& Vanderhal, E. (1997). Transformation of perception of trauma by child survivors of the Holocaust in group therapy. Journal of Contemporary Psychotherapy, 27 (2), 157-171. 
Valle, R.S. \& King, M. (1978). Existential-Phenomenological Alternatives for Psychology. New York: Oxford University Press.

Wardi, D. (1994). Bonding and separatedness, two major factors in the relations between Holocaust survivors and their children. Clinical Gerontologist, 14 (3), 119-131.

Weiss, S. \& Durst, N. (1994). Treatment of elderly Holocaust survivors: How do therapists cope? Clinical Gerontologist, 14 (3), 81-98.

Williams, S.S. (1993). The impact of the Holocaust on survivors and their children. [Electronic data tape]. Judaic Studies Program - University of Central Florida.

Yeheskel, A. (1995). The intimate environment and sense of coherence among Holocaust survivors. Social Work in Health care, 20 (3), 25-35.

Yehuda, R., Kahana, B., Southwick, S.M., \& Giller, E.L. (1994). Depressive features in Holocaust survivors with PTSD. Journal of Traumatic Stress, 7 (4), 699-704.

Yehuda, R., Kahana, B., Binder-Brynes, K., Southwick, S.M., Mason, J.W., \& Giller, E.L. (1995a). Low urinary cortisol excretion in Holocaust survivors with PTSD. American Journal of Psychiatry, 152 (7), 982-985.

Yehuda, R., Kahana, B., Schmeidler, J., Southwick, S.M., Wilson,S., \& Giller, E.L. (1995b). Impact of cumulative lifetime trauma and recent stress on current PTSD symptoms in Holocaust survivors. American Journal of Psychiatry, 152 (12), 1815-1817.

Yehuda, R., Elkin, A., Binder-Brynes, K., Kahana, B., Southwick, S.M., Schmeidler, J., \& Giller, E.L. (1996). Dissociation in aging Holocaust survivors. American Journal of Psychiatry, 153 (7), 935-940.

Yehuda, R., Schmeidler, J., Siever, L.J., Binder-Brynes, K., \& Elkin, A. (1997). Individual differences in PTSD symptom profiles in Holocaust survivors in concentration camps or in hiding. Journal of Traumatic Stress, 10 (3), 453-461. 
APPENDIX A

APPLICATION FOR APPROVAL OF RESEARCH INVOLVING HUMAN SUBJECTS 
1. PROJECT TITLE: A EHENOMENOLOGICAL PERSPECTIVE OF THE LIVED EXPERIENCES OF JEWIS YCECCAUST SURVIVORS SEEKING HEALTA IARE IN THE UNITED STATES TODAY.

2. PRINCIPAL DVVESTIGATOR: Marsha Berger SSn: $206-42-6905$

Address: 2301 SW 19th Street Plantation, Florida -33317 Phone *: 954-792-4462

Position: I I Faculty $\left[{ }_{X}\right]$ Graduate Student I ] Undergraduate Student I J Other (Specify)

3. FACULTY SUPERVISOR (if PI is a student): Kathleen Blais

4. STATUS OF PROJECT REVIEW:

[X ? New projest I ] Revision of previously approved project l ] Continuation of approved project

5. BRIEF DESCRIPTION OF SLBJECTS

Number of subjecis: $6-10$

Check all of the following calegories that deseribe your research subjects:

[X] Males

I $X$ Females

(1) Minors (under 18 years old)

1 ] Siudents (Please Specify):

1 I Persons With Physical Disabilities (Please Specify):

( ) Persons With Mental/Psychological Disabilities (Please Specify):

1 ] Persons With Physical or Mental Health Problems (Please Specify):

I $\mathrm{x}]$ Persons With No Known Dicabilities and No Known Health Problems

1 I Prisoners

( ) Pregnant women. feruses. feul material or placenta (Please Specify):

(1) Persons in Some Type of Proerm (Please Specify):

( $x$ ) Other Peninent Information (Please Specify): Jewish survivors of the Nazi Holocaust

6. TYPE OF REVIEW REQUESTED (See pages 6 \& of the Information for Experimenters booklet):

1 I Exempl: Category (s):

IX I Expediled Review: Caregory w(s): 9

| I Full URC Review (Can be neilher Exemplad nar Expediled) 


\section{APPLICATION FOR APPROVAL OF RESEARCH INVOLVING HUMAN SUBJECTS}

7. RESEARCH OBJECTIVES: The purpose of the study is to explore and describe the lived experiences of Jewish Holocaust survivors. The major research question is what is the experience of being a Jewish Holocaust survivor seeking health care in the United States today?

Understanding those experiences may direct the nurse in implementing creative and appropriate nursing interventions to provide comfort and assist in the survivor's adaptation to changes in their health status. This study will add to nursing's body of knowledge with respect to cultural sensitivity and competence, holistic care, and humanistic care as it relates to Jewish Holocaust survivors.

8. SUBJECT RECRUITMENT: The subjects of the study will be approximately 10 Jewish survivors of the Holocaust who were prisoners in Nazi concentration camps during World War II, who have had health care experiences in the United States. Included in the study will be English speaking, Jewish men and women, of any age, who now reside in South Florida, have spoken about their Holocaust experience previously, and are willing to be interviewed. Excluded from the study will be any individual with known neurological deficits, known psychiatric disorders, or known unstable medical conditions, such as unstable angina or unstable hypertension. Also excluded would be anyone who has demonstrated severe emotional upset when previously speaking about their experience.

The participants will be referred by the Holocaust documentation center at Florida International University and by individuals personally known to the researcher. The 
subjects will be contacted initially by telephone. The purpose of the study will be explained to them. If the subjects are then willing to be interviewed, an appointment at a place that will provide privacy and time that is acceptable to the participant will be made.

9. BENEFITS: A very significant benefit of participation in the study is that if the survivors choose to speak about their Holocaust experience it helps to commemorate the survivor's loved ones who perished in the Holocaust. Another benefit of the study would be the knowledge that improved nursing care might result from a better understanding of Holocaust survivor's needs.

10. INFORMED CONSENT: The researcher will fully disclose the nature of the study, as well as the risks and benefits. The subjects will be given an opportunity for explanation or clarification at any time. Informed consent will be documented by having a consent form signed (Appendix B).

11. CONFIDENTIALITY OF DATA: All data will be kept in the strictest confidence. The individual's names will be excluded from all audiotapes and printed material. The interviewees will be identified by fictitious names. All audio tapes, transcriptions, and notes will be kept in a locked file accessible to the researcher only, for a period of three years, after which they will be appropriately destroyed.

12. METHODS AND PROCEDURES: The design for this study will be descriptive, qualitative, and phenomenological. Colaizzi's method of phenomenological analysis will be used. This is a reductionistic process of content analysis with the end result being extraction of the essence of the Hotocaust survivor's experience as it relates to their health care needs. The procedurat steps are as follows:

1. Audio taping the subject's description of the phenomenon. 
2. Transcribing of the tapes.

3. Reading the transcripts in their entirety.

4. Returning to the transcripts and extracting significant statements that pertained to the phenomenon being explored.

5. Trying to spell out the meaning of each significant statement.

6. Organizing the aggregate formalized meanings into clusters of themes.

7. The results of the previous steps are integrated into an exhaustive description.

8. The researcher returns to the participants for validation of the description.

9. If new data are revealed during the validation, incorporating them into the exhaustive description.

The researcher's assumptions and biases will be bracketed so that personal beliefs or feelings about the phenomenon will not interfere with the interpretation of the data. In an attempt to do this, a diary will be kept of the researcher's feelings before and during the data collection process and while interpreting the data.

13. STIMULUS MATERIALS: No questionnaires will be used. The interviews will be personally conducted by the researcher only. There will be one open ended question "Tell me what it is like for you, as a Holocaust survivor, to seek health care in the United States today?"

14. RISKS TO SUBJECTS: There are no anticipated risks to the subjects. If any emotional distress should arise, as the Holocaust survivor relates his past experiences, the interview will be terminated if the subject chooses, and a referrel made to Jewish Family Services, as explained in the consent form (Appendix B). 
I agree to follow the procedures oullined in this summary deseripuion and any atwehments. I understand that no coniacl may be initisled with subjocts until I have received approval of these procedurcs from the URC and have complied with any modifications required in connocion with thal approval. I undersiand that additions 10 or changes in the procedures involving human subjects can only be made after approval of the URC. I undersiand Ihat I musi promptly repon to the URC any problems with the rights or welfare of the human suhjects. I undersiand and will follow Florida International University's policies conceming research with human subjccls. I will do everything in my power 10 prolect the rights and welfare of human subjecls in my research project.

A PHENOMENOLOGICAI,

PERSPECTIVE OF THE LIVED EXPERIENCES OF JEWISH HOLOCAUST SIIRVIVORS

(ponnt lille of project here) SEEKING HEAT TIJ EARF -N TUE [NTTTED STATES TORAY

Signature bf Principal Inveripator

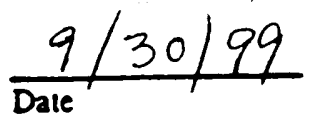

Marsha Berger

Prnied name of Principal Investigator

If the PI is a student. the faculty supervisor must sign below.

I have read this application and assume responsibility for its accuracy and for supervision of the proposed research project.

Signature of Faculiy Supervisor

$\frac{j 0.4 .99}{\text { Date }}$

KATHLEEN BLAIS

Prinied name of Faculty Supervisor

ACTION RECOMDENDED BY URC • FOR URC use Only"•

Date: O. B CSSI 4Approved I I Changesiclarifications Requested I I Require Full Board Revieu. Signaluff of URC Craiptosion
DOUC A A BFFin

Princed name of URC Chaiperson

Date:

( I Approved I J ChangestClarifications Requested

l I Requirs Full Board Reviex.

Signarure of URC Chaiperson

Date:

Signalure of URC Chaiperson 


\section{APPENDIX B}

\section{INFORMED CONSENT}

In signing this form, I am giving consent to be interviewed by Marsha Berger, a registered nurse and graduate student at Florida International University. I understand that I will be part of a research study that will focus on the experiences and needs of Jewish survivors of the Nazi Holocaust seeking health care in the United States today. I understand that I was selected to participate in this study because I was a prisoner in Nazi concentration camps during World War II. This study will hetp develop a better understanding of the experiences, especially health care experiences, of survivors so that appropriate nursing interventions may be created to help meet the special needs of all Jewish Holocaust survivors.

I understand that I will be interviewed and audiotaped in a mutually agreed upon location that will provide privacy, at a time that is convenient to me. I will be asked a question about my experience seeking health care in the United States today. The interview will take approximately 2 hours to complete. If I should become too tired to complete the interview, the session will end and will be completed at another time. I also understand that the researcher may need to contact me again to validate her understanding of the information given.

This interview is granted voluntarily. I have been informed that even after the interview begins I may refuse to answer any questions, and it will remain my decision if I should choose to terminate the interview at any time without consequences. I have also been informed that refusal to participate will not effect any health or social services that I might need.

There are no anticipated risks to my participation in this study. In the event that the questioning causes any emotional distress, the session will be terminated if I choose, and a referral will be made to Jewish Family Services for support.

One benefit to participation in this study is that it helps to commemorate my loved ones, and all who perished in the Holocaust. Another benefit would be the improved nursing care that would result from a better understanding of Holocaust survivors' needs.

I understand that the information obtained during this interview will be kept in the strictest confidence. The interviews will be audio taped. The audiotapes will not include any identifying information because the tapes may be transcribed by a person other than the researcher. My name will not appear on any printed material. All data will be kept in a locked file cabinet in the researcher's home for a period of three years, after which it will be appropriately destroyed.

I understand that if I have any questions or if I am interested in obtaining the results of this study I may contact Marsha Berger at (954)792-4462 or Dr. Kathleen Blais, Faculty Supervisor, Florida International University, at (305)919-5915. 
APPENDIX C

LETTER TO THE HOLOCAUST DOCUMENTATION CENTER 


\section{Florida International University}

October 7, 1999

Holocaust Documentation and Education Center

Florida International University

$3000 \mathrm{NE} 151^{\text {st }}$ Street

N Miami, Florida 33181

Attention: Rita Hofrichter, Director

I am Marsha Berger's Supervisor and Major Chair person for her thesis committee. I am a full professor at Florida International University. Marsha is very sincere in her effort to learn about the lived experiences of Jewish Holocaust survivor's as they seek health care in the United States today. In the four years that I have known Marsha, I have found her to be a serious student and ethical person. Thank you for your cooperation in helping her find Holocaust survivors to interview.

Very truly yours,

Kathleen Blais, Rฬ, EdD

Florida International University

$3000 \mathrm{NE} 151^{\text {st }}$ Street

N. Miami, Florida 33181

(305) 919-5915 
APPENDIX D

APPROVAL OF RESEARCH INVOLVING HUMAN SUBJECTS 


\section{Florida International University}

Date:

13 October 13, 1999

To:

Marsha Berger, BSN, RN, Master's Degree in Nursing Student Dr. K. Blais, Chairperson Thesis/Research Project-Report

From:

Douglas A. Coffin, RN, C.JPh.D., AR/p

SON URC Representative

Re:

Application for approval of research involving human subjects titled: “A phenomenological perspective of the lived experiences of Jewish holocaust survivors seeking health care in the United States today."

Cc: URC Chairperson

Your application has been approved for exempt and/or expedited status. Please be aware that you have agreed to follow the procedures outlined in your summary description and any attachments. You may not contact subjects until you have received this written notification of approval. You understand that any additions to or changes in the procedures involving human subjects can only be made after approval of the URC or its departmental representatives. You understand that you must promptly report to the URC any problems with the rights or welfare of the human subjects. You understand and will follow Florida International University's polices and procedures concerning research with human subjects. You will do everything with your power to protect the rights and welfare of human subjects in your research project.

I requested a second review of the study to validity the phenomenological approach since my area is more quantitative than qualitative. The reviewer found the study to have strong methodological coherence.

Good luck on your project/research and congratulations. 